\title{
Tumor Receptor Imaging
}

\author{
David A. Mankoff ${ }^{1-3}$, Jeanne M. Link ${ }^{1}$, Hannah M. Linden ${ }^{2,3}$, Lavanya Sundararajan ${ }^{2,3}$, and Kenneth A. Krohn ${ }^{1}$ \\ ${ }^{1}$ Division of Nuclear Medicine, University of Washington, Seattle, Washington; ${ }^{2}$ Department of Medicine, University of Washington, \\ Seattle, Washington; and ${ }^{3}$ Seattle Cancer Care Alliance, Seattle, Washington
}

Tumor receptors play an important role in carcinogenesis and tumor growth and have been some of the earliest targets for tumorspecific therapy, for example, the estrogen receptor in breast cancer. Knowledge of receptor expression is key for therapy directed at tumor receptors and traditionally has been obtained by assay of biopsy material. Tumor receptor imaging offers complementary information that includes evaluation of the entire tumor burden and characterization of the heterogeneity of tumor receptor expression. The nature of the ligand-receptor interaction poses a challenge for imaging - notably, the requirement for a low molecular concentration of the imaging probe to avoid saturating the receptor and increasing the background because of nonspecific uptake. For this reason, much of the work to date in tumor receptor imaging has been done with radionuclide probes. In this overview of tumor receptor imaging, aspects of receptor biochemistry and biology that underlie tumor receptor imaging are reviewed, with the estrogen-estrogen receptor system in breast cancer as an illustrative example. Examples of progress in radionuclide receptor imaging for 3 receptor systemssteroid receptors, somatostatin receptors, and growth factor receptors - are highlighted, and recent investigations of receptor imaging with other molecular imaging modalities are reviewed.

Key Words: tumors; receptors; imaging

J Nucl Med 2008; 49:149S-163S

DOI: 10.2967/jnumed.107.045963

C

ancer therapy is becoming increasingly directed and specific, taking advantage of biologic targets that are uniquely expressed or markedly overexpressed in tumors. Tumor receptors have been some of the earliest targets for cancer therapy, with notable successes in the treatment of endocrine-related cancers such as breast, prostate, and thyroid cancers (1-3). Advances in molecular cancer biology have revealed an ever-increasing number of tumor targets, many of which are receptors, such as the epidermal growth factor (EGF) receptor (EGFR) (4). The ability to measure the expression of tumor receptors is essential for selecting patients for receptor-targeted therapy (2). Although this information traditionally has been obtained by

Received Sep. 26, 2007; revision accepted Jan. 2, 2008.

For correspondence or reprints contact: David A. Mankoff, Radiology, G-2100, Seattle Cancer Care Alliance, 825 Eastlake Ave. East, P.O. Box 19023, Seattle, WA 98109-1023.

E-mail: dam@u.washington.edu

COPYRIGHT @ 2008 by the Society of Nuclear Medicine, Inc. in vitro assay of biopsy material, recent studies have highlighted the complementary value of tumor receptor imaging for measuring regional tumor receptor expression, which can be quite heterogeneous.

Tumor receptor imaging emphasizes important emerging themes in molecular imaging: characterizing tumor biology, identifying therapeutic targets, and delineating the pharmacodynamics of targeted cancer therapy $(5,6)$. The advantages of imaging include noninvasiveness, the ability to measure receptor expression for the entire disease burden and thereby to avoid the sampling error that can occur with heterogeneous receptor expression, and the potential for serial studies of the in vivo effects of a drug on the target. A very practical consideration is that imaging can assess receptor expression at sites that are challenging to sample and assay, such as bone metastases. This review discusses receptor pharmacology, the biology of tumor receptors, and special considerations for tumor receptor imaging, with the estrogen receptor (ER) as an illustrative example. This discussion is followed by highlights of recent work in the imaging of steroid receptors, somatostatin receptors (SSTRs), and growth factor receptors, as examples of 3 different types of tumor receptors. These topics were selected from a broad range of investigations in tumor receptor imaging (Table 1).

\section{RECEPTOR PHARMACOLOGY}

Common to all receptors is the interaction of a ligand and the receptor, in which specific binding of the ligand to the receptor results in downstream biochemical or physiologic changes $(7,8)$. Ligand-receptor binding can activate or inhibit downstream processes through a variety of mechanisms, such as G-protein activation (e.g., PAR1), tyrosine kinase activation (e.g., EGFR), or activation of transcription (e.g., ER) (9-11). Ligands that cause physiologic changes with receptor binding, typically the naturally occurring ligands, are called agonists. Ligands that bind to the receptor and block the binding of agonists but that do not activate changes are known as antagonists. Drugs directed toward tumor receptor systems most frequently use a receptor antagonist, for example, tamoxifen, which blocks estrogen binding to the ER. Alternatively, some drugs lower the level of an agonist to decrease ligand-receptor interactions, for example, levothyroxine, which suppresses 
TABLE 1

Selected Examples of Tumor Receptor Imaging Agents

\begin{tabular}{|c|c|c|}
\hline Target & Imaging probe & Modality \\
\hline \multicolumn{3}{|l|}{ Small-molecule ligands } \\
\hline AR & ${ }^{18} \mathrm{~F}-\mathrm{FDHT}(64)$ & PET \\
\hline \multirow[t]{2}{*}{ ER } & 11- $\beta$-Methoxy-17- $\alpha^{-123}$-iodovinylestradiol (179) & SPECT \\
\hline & ${ }^{18} \mathrm{~F}-\mathrm{FES}(52)$ & PET \\
\hline PR & $21-18$ F-fluoro-16- $\alpha$-ethyl-19-norprogesterone (65) & PET \\
\hline \multirow[t]{2}{*}{ Sigma-2 receptor } & $N$-(4-(6,7-dimethoxy-3,4-dihydroisoquinolin-2- ${ }^{1} \mathrm{H}$-yl)butyl) & PET \\
\hline & 2-(2-18F-fluoroethoxy)-5-methylbenzamide (180) & PET \\
\hline EGFR (tyrosine kinase) & ${ }^{11} \mathrm{C}$-gefitinib (181) & PET \\
\hline \multicolumn{3}{|l|}{ Peptide ligands } \\
\hline \multirow{3}{*}{ SSTR } & ${ }^{111}$ In-octreotide (101) & SPECT \\
\hline & ${ }^{68} \mathrm{Ga}-\mathrm{DOTA}$-octreotide (97) & PET \\
\hline & ${ }^{64} \mathrm{Cu}$-TETA-octreotide (100) & PET \\
\hline \multirow[t]{3}{*}{ EGFR } & ${ }^{111}$ In-DTPA-EGF (121) & SPECT \\
\hline & ${ }^{68} \mathrm{Ga}-\mathrm{DOTA}-\mathrm{EGF}(182)$ & PET \\
\hline & Cy5.5-EGF (156) & Optical imaging \\
\hline \multirow[t]{3}{*}{$\alpha_{v} \beta_{5}$ Integrins } & ${ }^{18 F-g a l a c t o-R G D ~(183) ~}$ & PET \\
\hline & RGD-USPIO (155) & MRI \\
\hline & RGD-Cy5.5 (184) & Optical imaging \\
\hline \multirow[t]{3}{*}{ Bombesin receptors } & {$\left[{ }^{111}\right.$ In-DTPA-Pro1,Tyr4]bombesin (185) } & SPECT \\
\hline & ${ }^{64} \mathrm{Cu}$-DOTA-[Lys3]bombesin (186) & PET \\
\hline & Bombesin-CLIO (Cy5.5) (187) & Optical imaging, MRI \\
\hline \multicolumn{3}{|c|}{ Monoclonal antibodies and fragments } \\
\hline \multirow[t]{5}{*}{ HER2 } & ${ }^{68} \mathrm{Ga}-\mathrm{DOTA}-\mathrm{F}\left(\mathrm{ab}{ }^{\prime}\right)_{2}$-trastuzumab (146) & PET \\
\hline & ${ }^{111}$ In-DTPA-trastuzumab (133) & SPECT \\
\hline & Polylactic acid nanoparticle-trastuzumab (161) & Ultrasound \\
\hline & RhodG-trastuzumab (164) & Optical imaging \\
\hline & $\begin{array}{l}\text { (Avidin-Gd)-biotinylated anti-HER2/neu } \\
\text { monoclonal antibody (159) }\end{array}$ & MRI \\
\hline \multirow[t]{2}{*}{ EGFR } & ${ }^{64} \mathrm{Cu}$-DOTA-cetuximab (131) & PET \\
\hline & Cy5.5-cetuximab (162) & Optical imaging \\
\hline
\end{tabular}

thyroid-stimulating hormone levels in the treatment of thyroid cancer (12).

The ligand-receptor interaction is a bimolecular chemical reaction. The concentration of the receptor is typically quite low; for example, the level of ER expression in breast cancer is in the range of 3-100 fmol per milligram of protein (13). Furthermore, receptor-specific ligands bind to receptors with a high affinity and often with a very low ligand-receptor dissociation rate (7). The combination of a low receptor concentration and a high ligand-receptor affinity leads to a low overall capacity for ligand-receptor binding. This property is helpful for drug therapy, in which the goal is to saturate the receptor with an antagonist to prevent receptor activation by an agonist. However, the high-affinity, low-capacity ligand-receptor binding reaction presents a challenge for imaging in that the number of molecules that can contribute to the specific receptor image is small. Furthermore, nonspecific binding of ligands to plasma proteins and nontarget tissues can limit imaging agent delivery and contribute to nontarget image background. For these reasons, imaging of receptor binding, as opposed to imaging of an enzymatic reaction, such as glucose phosphorylation, in which it is difficult to saturate the uptake mechanism, is challenging. It is important for receptor imaging probes to have very low molecular concentrations. Even small molar quantities of imaging agents may saturate receptors, limiting the ability to visualize receptor expression and increasing the background of nonspecific binding (14). Therefore, molecular imaging of tumor receptors has been mainly confined to radionuclide imaging (PET and SPECT), with which it is possible to generate images with micromolar to picomolar concentrations of imaging probes.

It is important to note that the criteria for a suitable receptor imaging agent are different from those for a receptor-targeted drug. Although selectivity for the drug requires an effect on the tumor in the absence of appreciable toxicity from nontarget tissue drug action, the requirement for high target uptake and low image background in imaging places constraints on radiopharmaceutical selectivity and background clearance that can be even more stringent than those for therapeutic drugs.

The estrogen-ER system is an illustrative example of a receptor system with relevance to cancer (15). The ER is 
important in female reproductive physiology and is selectively expressed in a variety of normal tissues-most notably, breast, uterus, ovary, bone, and pituitary tissues (9). Estradiol is a naturally occurring agonist ligand for the ER. The molecular mechanism of estradiol action through the ER has been well studied $(3,9)$. Estradiol is lipophilic, allowing access across cell membranes to the ER, a nuclear receptor. The ER has 2 receptor subtypes: ER- $\alpha$ and ER- $\beta$. ER- $\alpha$ serves mainly as an activator of downstream events related to breast and female sex organ function. The function of ER- $\beta$ is less well understood; in some situations, ER- $\beta$ may inhibit ER- $\alpha$ by forming a heterodimer with ER- $\alpha$ (16). Estradiol binding to ER- $\alpha$ in the nucleus results in dimerization of the receptor and allows interactions with specific DNA sequences known as the estrogen response elements (15), leading to the selective regulation of target gene transcription.

ER activation leads to different physiologic actions in different tissues. Much of the tissue specificity appears to be attributable to coregulators that interact with the ER homodimer and the estrogen response elements and that can affect the pattern of gene transcription (15). In the uterus, estrogens bound to the ER stimulate endometrial growth and are critical in maintaining a functioning uterineplacental unit during pregnancy. Estradiol promotes new bone formation and is important in maintaining bone mineral density, especially in women $(9,17)$. Also, estrogens affect the cardiovascular system, mainly through their beneficial effect on serum lipids. In breast tissue, estradiol promotes ductal epithelial cell proliferation and is a key component stimulating lactation. Estrogens are established growth factors for endometrial and many breast cancers. Over $70 \%$ of breast cancers express the ER, and estradiol and other estrogens provide a key stimulus for tumor growth and a target for endocrine system-based therapy (endocrine therapy) (2,3,18-21). Tissue-specific coregulators interact with ligand-ER dimers and may affect the physiologic actions of different ligands when they bind to the ER. For example, drugs known as selective ER modulators (SERMs) exhibit various degrees of either ER agonist or antagonist behavior in different tissues, an effect thought to be based on the differential expression of ER coregulators in different tissues (9).

The circulating levels of agonists for the ER are variable but are tightly regulated in normal human physiology (17). The agonist estradiol has 2 sources: synthesis in the ovary in premenopausal women and conversion from adrenal steroids, mainly through aromatization (and aromatase enzymes) present in a variety of tissues-most notably, fat, breast tissue, and breast cancers $(22,23)$. Premenopausal levels of estradiol vary, depending on the phase of the menstrual cycle, reaching levels as high as $500 \mathrm{pg} / \mathrm{mL}$ $(1.7 \mathrm{nM})$ at midcycle (17). In postmenopausal women and men, the levels are generally less than $30 \mathrm{pg} / \mathrm{mL}(0.1 \mathrm{nM})$. Estradiol is very lipophilic and is generally present at slightly higher concentrations in tissues with higher fat contents, providing an opportunity for nonspecific uptake. Circulating estradiol is mainly protein bound. This binding occurs with a high affinity but a low capacity to sex hormone-binding globulin (SHBG or SBP) and with a low affinity but a high capacity to albumin (24,25). Much of circulating estradiol is bound to SHBG, and the remainder is bound to albumin (24). Binding to both SHBG and the ER appears to be important for normal estrogen physiology and also appears to be important for ER imaging agents (25-27). One of the physiologic roles of SHBG appears to be the regulation of estrogen metabolism (28). Estradiol is highly metabolized in the liver to estrone and conjugates of both estradiol and estrone (29) and enters a cycle of enterohepatic circulation (30-32). Binding to SHBG, extraction by the liver, and reabsorption of conjugated estrogens in the small intestine all play important roles in regulating estradiol levels in normal physiology $(24,28)$.

Considerations for imaging of the ER include the need for low injected molar doses to remain below physiologic levels (typically $30 \mathrm{pg} / \mathrm{mL}$ or higher), the need for imaging agents to bind to both the ER and the transport protein (SHBG), normal routes of estrogen metabolism and excretion, and nonspecific binding in the blood and lipophilic tissues (33). These considerations are discussed in more detail in the following sections as we examine other aspects of tumor receptor imaging. Overall, the complex nature of ER physiology emphasizes the need for a detailed understanding of receptor pharmacology and physiology in developing tumor receptor imaging approaches.

\section{BIOLOGY AND PHYSIOLOGY OF TUMOR RECEPTORS}

The biologic role of most receptor systems important in cancer is derived from their role in the tissue of cancer origin. In general, tumor receptors are expressed in the parent cell lineage and have an established physiologic function. For example, ER expression is essential to the function of normal mammary gland epithelial cells $(9,15)$. When estradiol binds to ductal epithelial ER, it stimulates mammary gland growth, maintenance, and physiologic function $(9,15)$. Many tumor receptors also play an important role in promoting carcinogenesis or tumor growth, as is the case for steroid receptors in breast and prostate cancer (34). The dependence on the receptor pathway for tumor growth makes the receptor an ideal target for therapy, because interruption of the receptor-initiated signal will result in a cessation of tumor growth and often tumor cell death $(3,10)$.

For many tumor receptors expressed in the normal parent cell lineage, the receptors are expressed at levels comparable to those in normal cells, and tumor growth stimulation occurs in concert with other factors contributing to the dysregulation of tumor cell growth. This mechanism appears to be the case for steroid receptors, although gene amplification may occur in some cases (35). For other 
receptors, overexpression of the receptors leads to aberrant stimulation of the signaling pathway. Examples of this mechanism include EGFR in lung cancer and HER in breast cancer $(3,10,36)$. In this situation, aberrant expression (overexpression) becomes an important marker for the activation of the pathway and predicts the likely efficacy of therapy directed against the target. For example, the overexpression of HER2 is highly predictive for a response to trastuzumab, a monoclonal antibody directed against HER2 (37). In all cases, knowledge of the levels of receptor expression, which may vary considerably in different tumors and even in different sites in the same tumor, is required to infer the likelihood that receptor-directed therapy will be effective.

For tumor receptor systems, considerable variability exists in both ligands and receptors. Ligands may be naturally occurring small molecules, such as estradiol and testosterone, synthesized and secreted in endocrine organs, such as the adrenal gland, ovary, and testis, or peptides assembled and secreted by different types of endocrine cells (38). Receptors can be located on the cell membrane, for example, EGFR and SSTRs (36), or localized within the cell, for example, steroid receptors in the nucleus (9). In some cases, such as steroid receptors, the binding of the agonist ligand to the receptor is well understood, and there is a clear causal relationship between binding and pathway activation (15). In other cases, such as HER2, the pharmacologic significance of ligand-receptor binding in activating the pathway is less well understood; however, receptor-targeted therapy can still be effective at interrupting the signaling pathway through antagonism $(10,39)$.

The approaches to tumor receptor-targeted therapy vary. In many situations, receptor-targeted antagonists bind to the receptor and block the normal agonist ligand from binding and activating the pathway; for example, the drugs tamoxifen and flutamide block the ER and the androgen receptor (AR), respectively $(9,40,41)$. Many receptor-blocking agents have structures relatively similar to that of the natural ligand and are designed to bind to the same site as the agonist; examples are antiestrogens and antiandrogens. Blocking agents can also bind through immune recognition; for example, the agents trastuzumab and cetuximab bind to HER2 and EGFR, respectively (36).

An alternative therapeutic strategy is to deplete the ligand. This approach has been extraordinarily effective for estrogens and the ER in breast cancer, for which the use of aromatase inhibitors has met with considerable success $(22,23)$. With aromatase inhibitors, the drug is not a receptor antagonist ligand but rather is an enzyme inhibitor that blocks the synthesis of the naturally occurring agonist ligands estradiol and estrone (22). Aromatase inhibitors block the conversion of adrenal steroids to estrogens, the major source of estrogen in postmenopausal women, lowering estrogen concentrations both in the serum and in the local tumor environment (42). Aromatase inhibitors are now first-line adjuvant and primary metastatic breast cancer treatments in postmenopausal patients with ER-expressing tumors (43).

Despite the importance of tumor receptors in carcinogenesis and tumor growth, tumor receptors are not always effective targets for cancer treatment, because some cancers can sustain growth independently of receptor activation. In some situations, growth independence is accompanied by a loss of or a reduction in receptor expression, such as in ERnegative breast cancers (3). In such situations, the absence of receptor expression indicates a negligible chance of success of receptor-targeted therapy. In other situations, even though a receptor is still present, receptor pathway activation is not required for growth. For example, although $70 \%$ of breast cancers express the ER, only $50 \%-75 \%$ of ER-expressing primary breast cancers respond to endocrine therapy, and even fewer recurrent tumors respond (3). Redundant growth pathways may make the receptor system no longer necessary to sustain tumor growth. The latter situation appears to occur with breast cancers that both express ER and overexpress HER2 and that are often resistant to endocrine therapy, even when ER expression is preserved (44). These examples illustrate that although tumor receptor expression is necessary for a functional pathway, receptor expression does not necessarily guarantee the success of receptor-targeted therapy. The approach to patient selection is therefore sequential. The first step is the assay of receptor expression, because the absence of receptor expression invariably indicates that the receptor pathway is not a suitable target for therapy. After the selection of patients with receptor expression, the next step is to show that the pathway is functional and required, typically by assessing the response to receptor-targeted therapy. This clinical paradigm sets the stage for the goals of tumor receptor imaging.

\section{SPECIAL CONSIDERATIONS FOR TUMOR RECEPTOR IMAGING}

Tumor receptor imaging poses unique challenges for the design of radiopharmaceuticals and imaging approaches. Most receptors have high affinities for their ligands and are active at nanomolar concentrations of the ligands. For this reason, radiopharmaceuticals with high specific activity are essential. Even small molar quantities of an imaging agent may saturate a receptor and limit the ability to visualize receptor expression $(14,33)$. For this reason, molecular imaging of tumor receptors has been most successful with radionuclide imaging (PET and SPECT), with which it is possible to generate images with nanomolar amounts of imaging probes. For larger molecules, such as peptides and monoclonal antibodies, other labels suitable for optical imaging, MRI, and ultrasound imaging are possible (Table 1); however, for small-molecule receptor imaging agents, such as labeled steroids for steroid receptors, radionuclide imaging appears to be the only feasible approach. The need for high specific activity (ratio of radioactive to nonradio- 
active molecules) also poses a challenge for radiopharmaceutical quality control (14,33). Specific activity often needs to be measured before each radiopharmaceutical administration to ensure that a failure to visualize the receptor is not the result of poor tracer-specific activity.

The choice of a label depends on the nature of the receptor imaging probe. For example, somatostatin imaging of neuroendocrine tumors entails the use of a labeled peptide closely related to the naturally occurring peptide hormone somatostatin (45). In this situation, the imaging molecule is large enough to enable the use of chelating groups and radiometal labels without a loss of receptor binding. A variety of somatostatin imaging agents have been successfully developed with both single-photon emitters $\left({ }^{111} \mathrm{In}\right.$ and $\left.{ }^{99 \mathrm{~m}} \mathrm{Tc}\right)$ and positron emitters $\left({ }^{68} \mathrm{Ga}\right.$ and $\left.{ }^{64} \mathrm{Cu}\right)(46-48)$.

For smaller molecules, the isotope label may significantly affect binding to the receptor, binding to transport proteins, and in vivo metabolism. In this situation, the choices of radionuclide and labeling position for imaging may be relatively limited, such as for ER imaging agents (14). Considerable work has been done with both singlephoton-emitting and positron-emitting halides for ER imaging (49-51), but studies have suggested that ${ }^{18} \mathrm{~F}$ is the most attractive label for PET ER imaging (14). Fluorine is a small halogen in which substitutions can be made at several positions of the estrogen while preserving binding affinities for both ER and SHBG $(52,53)$. Furthermore, ${ }^{18} \mathrm{~F}$ has a sufficiently long half-life to permit multistep synthesis of ligands $(52,54)$ as well as uptake by target tissue and elimination by nontarget tissue during imaging $(14,55)$; in addition, the use of PET permits quantitative imaging of regional receptor binding.

For small molecules, the location of the label can also be important. For ER imaging, ${ }^{18} \mathrm{~F}$ substitution in the $16-\alpha$ position for the steroidal analog estradiol to yield ${ }^{18} \mathrm{~F}-16-\alpha-$ $17-\beta$-fluoroestradiol $\left({ }^{18} \mathrm{~F}-\mathrm{FES}\right)$ resulted in highly selective uptake by target tissue, with a uterus-to-blood ratio of 39 (52). Changing the molecule or labeling can have unexpected results. For example, ${ }^{18} \mathrm{~F}$-labeled moxestrol $\left({ }^{18} \mathrm{~F}-\right.$ FMOX), another ER imaging agent, was developed with the goal of decreased metabolism and increased ER binding. Preclinical studies in vitro and in rats demonstrated better ER binding in vitro and increased uterine uptake in immature rats for ${ }^{18} \mathrm{~F}$-FMOX than for ${ }^{18} \mathrm{~F}$-FES $(26,56)$. However, ${ }^{18} \mathrm{~F}$-FMOX performed poorly in human studies. The explanation for these findings was that poor binding of ${ }^{18}$ F-FMOX to the steroid transport protein, SHBG, likely limited its utility in humans. Rats lack SHBG (25); therefore, ${ }^{18} \mathrm{~F}$-FMOX was an effective imaging agent in rats. In this example, a change in the imaging molecule that promoted increased ER binding unfavorably altered the binding to SHBG, resulting in a compound with poorer performance. This example illustrates the demanding nature of radiopharmaceutical design for tumor receptor imaging and the need for validation at each step of development, from the laboratory bench to the bedside.
For these reasons, considerable preclinical work and early testing in patients are necessary to develop and validate receptor imaging agents (33). In vitro studies must confirm the high-affinity receptor binding of a radiopharmaceutical as a starting point for development. Subsequently, in vitro and in vivo animal models must demonstrate that binding is specific to the receptor and that an excess of the nonlabeled natural ligand, or a suitable substitute specific for the receptor, can displace or block the binding of the radiopharmaceutical. In vivo clearance, metabolism, and biodistribution in preclinical models and early patient studies must confirm sufficient tracer clearance to visualize uptake in tumors but sufficiently slow blood clearance and metabolism to permit uptake in receptor-rich tissues. Defining the nature of labeled metabolites is also important, because some metabolites may bind to the receptor, whereas others may not. For example, in humans, ${ }^{18} \mathrm{~F}-\mathrm{FES}$-labeled metabolites are present mostly in the form of conjugates that do not bind to the receptor or have access to the nuclear receptor. These metabolites therefore contribute to nonspecific image background $(27,55,57)$. In addition, assessment of nonspecific binding is important; nonspecific binding must be sufficiently low to avoid interference with the visualization and quantification of tumor uptake at target sites.

Receptor imaging poses some additional challenges for image acquisition and analysis. Because the absence of receptor expression may be even more important than the presence of a receptor, the imaging approach must be able to quantify low levels of radiopharmaceutical uptake and reliably identify situations in which a tumor is present but the uptake of a receptor imaging agent is low or absent. This approach requires multimodality imaging. Combined functional imaging and anatomic imaging, such as PET/CT or SPECT/CT, may be essential for localizing tumor sites at which the uptake of a receptor imaging probe can be quantitatively interrogated. Because it may be difficult to identify active tumor sites by anatomic imaging alone, it may be necessary to align tumor receptor images with images obtained with another tumor imaging probe, such as ${ }^{18}$ F-FDG, to identify viable tumor. We used this approach for the ER imaging of breast cancer; ${ }^{18}$ F-FDG PET identified sites of active breast cancer at which to evaluate ER expression by ${ }^{18} \mathrm{~F}-\mathrm{FES}$ PET (Fig. 1). It may be beneficial to coregister different functional images; for example, for PET/CT and SPECT, the anatomic images may be used as the basis for coregistration. Finally, because radiopharmaceutical uptake may be at or close to background uptake in nontumor tissues, accurate correction for the imaging of physics-related background counts, such as scattered photons, is critical.

Another potential issue is separating the effects of imaging probe transport and binding in determining the overall image. It is possible that transport barriers will limit the in vivo access of the imaging probe to the site of tumor receptor expression. Therefore, it may be difficult to 


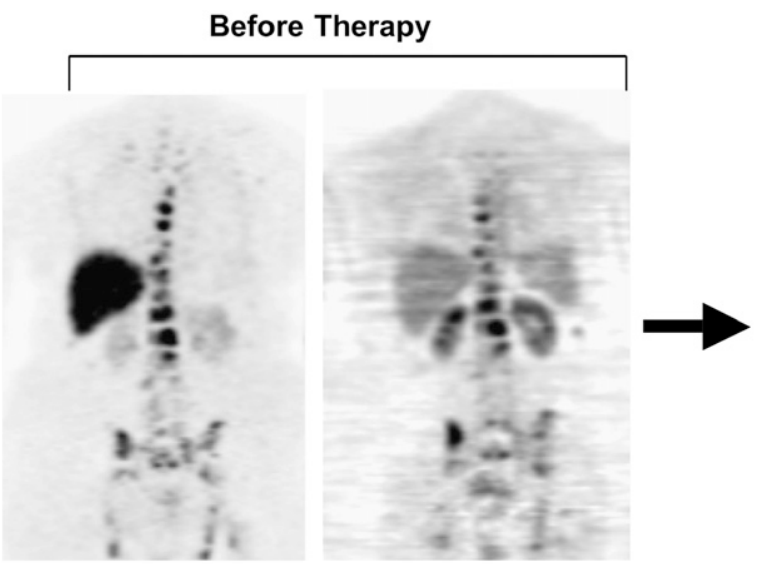

FIGURE 1. Examples of different patterns of ER expression measured by ${ }^{18} \mathrm{~F}-$ FES PET. Both patients had bone metastases arising from ER-expressing primary tumors, and both were treated with endocrine therapy. (A) For this patient, pretherapy ${ }^{18} \mathrm{~F}-\mathrm{FDG}$ and ${ }^{18} \mathrm{~F}-\mathrm{FES}$ PET scans showed ${ }^{18} \mathrm{~F}-\mathrm{FES}$ uptake at all sites of active disease seen by ${ }^{18} \mathrm{~F}-\mathrm{FDG}$ PET. Follow-up 18F-FDG PET scan showed response to treatment after initiation of aromatase inhibitor therapy. (B) For this patient, there was no uptake at site of disease seen on ${ }^{18} \mathrm{~F}-\mathrm{FDG}$ PET scan (small arrow). Follow-up ${ }^{18} \mathrm{~F}-\mathrm{FDG}$ PET scan showed subsequent disease progression (small arrow) with endocrine therapy. (Reprinted with permission of (84).)

B

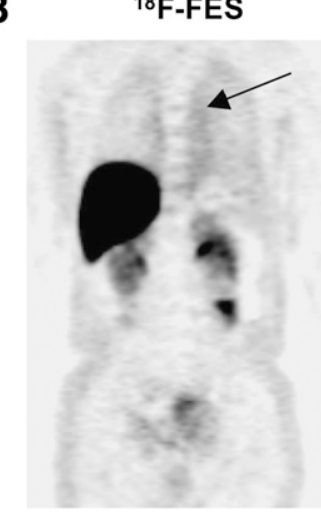

${ }^{18}$ F-FDG

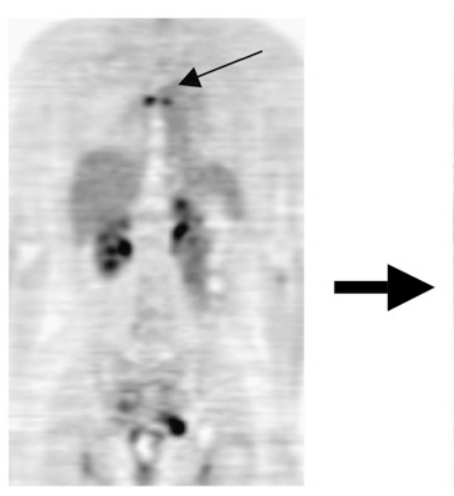

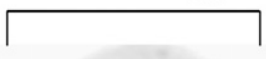

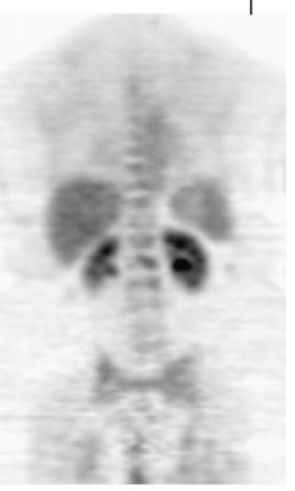

${ }^{18} \mathrm{~F}$-FDG

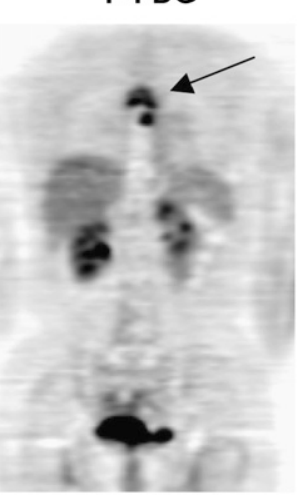

determine from a single static image whether the absence of radiopharmaceutical uptake at a tumor site is attributable to a lack of receptor expression or to a lack of delivery of the imaging probe. This is less likely to be an issue for small, lipophilic molecules, such as steroid imaging agents, but may pose an important consideration for peptides and especially monoclonal antibodies. In such situations, more sophisticated, dynamic imaging acquisitions may be required, along with more detailed and kinetic analyses.

\section{EXAMPLES OF TUMOR RECEPTOR IMAGING}

\section{Steroid Receptors}

Steroid receptor targets in cancer include the ER and the progesterone receptor (PR) in breast cancer and the AR in prostate cancer. We first briefly review experience in AR and PR imaging and then discuss ER imaging, for which the most experience with steroid receptor imaging has been obtained.

Parallel to efforts for ER imaging, a variety of compounds have been developed for PET of the AR; these have been directed mainly toward prostate cancer imaging (58$64)$. AR imaging has proved to be somewhat more challenging than ER imaging, perhaps because of the relatively tighter binding of androgens than of estrogens to SHBG; the latter property may limit the delivery of the imaging agent over the time scale of PET, even though tight binding of the AR imaging agent to SHBG appears to be important in generating $\mathrm{AR}$ images $(25,58)$. Preclinical studies in baboons, which have SHBG similar to that in humans, indicated that $16-\beta-{ }^{18} \mathrm{~F}$-fluoro-5- $\alpha$-dihydrotestosterone $\left({ }^{18} \mathrm{~F}-\mathrm{FDHT}\right)$ was a promising compound for PET (58). Early studies with ${ }^{18} \mathrm{~F}$-FDHT showed promise for the imaging of regional AR expression in prostate cancer $(59,61)$. Larson et al. (61) reported significant ${ }^{18} \mathrm{~F}-\mathrm{FDHT}$ uptake in 7 patients with prostate cancer. Like that of ${ }^{18} \mathrm{~F}$ FES, ${ }^{18}$ F-FDHT metabolism was rapid, with $80 \%$ of radioactivity in the blood in the form of metabolites at $10 \mathrm{~min}$ after injection. Cancer treatment diminished ${ }^{18} \mathrm{~F}-\mathrm{FDHT}$ uptake in the subset of patients re-imaged after therapy in that study. Dehdashti et al. (59) studied 20 patients with prostate cancer by ${ }^{18} \mathrm{~F}-\mathrm{FDHT}$ PET and found evidence of uptake in $63 \%$ of the patients; ${ }^{18} \mathrm{~F}$-FDHT PET revealed a substantial number of tumor sites that had not been identified by conventional imaging. Furthermore, in a subset of 12 patients who were re-imaged $1 \mathrm{~d}$ after the initiation of flutamide therapy, the imaging demonstrated a significant $(>50 \%)$ average decline in ${ }^{18} \mathrm{~F}$-FDHT uptake, indicating the ability to measure the pharmacodynamics of treatment with receptor antagonists. These encouraging results support the feasibility of PET AR imaging, and ongoing studies support the promise of imaging of AR expression in localizing prostate cancer and possibly predicting the response to antiandrogen therapy. 
Efforts to image the PR have been less successful $(56,65)$. In a study of 8 patients with primary breast cancer, Dehdashti et al. found that $21-{ }^{18} \mathrm{~F}$-fluoro- $16 \alpha$-ethyl-19norprogesterone was taken up in some tumors, but the level of uptake did not correlate with the level of PR expression (65). This result may have been attributable in large part to the relatively low affinity of progestins for the PR, with binding affinities that are orders of magnitude lower than those of androgens for the AR and of estrogens for the ER (56). Therefore, relatively high nonspecific binding compared with specific binding of imaging probes may limit their utility for PR imaging. Later studies also showed that the radiopharmaceutical tested had rapid metabolism in humans to a metabolite with poor receptor binding (66), a finding that was not predicted by preclinical models. Efforts to develop effective PR imaging agents continue (67).

The most experience to date with steroid receptor imaging for tumors has been obtained with ER imaging for breast cancer. Considerable efforts have been directed toward the development of radiopharmaceuticals for ER imaging (51). Early efforts to develop a labeling approach for PET focused on steroids labeled with bromine; promising early results were obtained with ${ }^{77} \mathrm{Br}-16 \alpha, 17 \beta$-estradiol in animals and humans $(68,69)$. Parallel efforts to develop ${ }^{123}$ I-labeled compounds for SPECT also yielded promising early results $(70,71)$. Although a variety of ER imaging agents have been tested and continue to be developed and tested $(14,53,72,73)$, the most successful ER imaging radiopharmaceutical to date has been ${ }^{18} \mathrm{~F}$-FES $(14,74) .{ }^{18} \mathrm{~F}-\mathrm{FES}$ has binding characteristics similar to those of estradiol for both the ER and the transport protein SHBG $(27,52)$. Typically, in humans, about $45 \%$ of ${ }^{18} \mathrm{~F}-$ FES in circulating plasma is bound to SHBG, and much of the remainder is weakly bound to albumin (27). The clearance and metabolism of ${ }^{18} \mathrm{~F}$-FES have been studied in both animals and humans $(55,57,75,76)$. Like other steroids, ${ }^{18} \mathrm{~F}$ FES is rapidly taken up by the liver and metabolized shortly after injection. As a result, early blood clearance is rapid, reaching a plateau 20-30 min after injection (55). To date, no toxicity or significant adverse reactions have been reported for ${ }^{18}$ F-FES. Radiation dosimetry studies have shown that organ doses associated with ${ }^{18} \mathrm{~F}$-FES PET are comparable to those associated with other commonly performed nuclear studies and that potential radiation risks are well within acceptable limits. The effective dose equivalent is $0.022 \mathrm{mSv} / \mathrm{Bq}(80 \mathrm{mrem} / \mathrm{mCi})$, and the organ that receives the highest dose is the liver, at $0.13 \mathrm{mSv} / \mathrm{Bq}$ (470 $\mathrm{mrad} / \mathrm{mCi})$ (77). The recommended injection is 222 $\mathrm{MBq}(6 \mathrm{mCi})$ or less. ${ }^{123}$ I-labeled compounds have also produced images of regional ER expression with acceptable radiation dosimetry $(70,78)$, albeit with somewhat lower image quality. The quantification of radiopharmaceutical uptake appears to be important for ER imaging, and this quantification is more challenging for SPECT than for PET.

${ }^{18} \mathrm{~F}$-FES uptake has been validated as a measure of ER expression in breast tumors. In 1988, Mintun et al. (79) reported an excellent correlation between ${ }^{18} \mathrm{~F}$-FES uptake measured in primary tumors on PET images and tumor ER concentrations measured in vitro by radioligand binding after excision for 13 patients with primary breast masses. A preliminary comparison of ${ }^{18}$ F-FES uptake with immunohistochemistry assays of biopsy material from patients with both primary and metastatic cancers also showed a good correlation $(80,80 a)$. Imaging results will not necessarily correlate perfectly with biopsy results. Differences between in vivo measures of ER expression by PET and in vitro assays of ER expression are to be expected, especially in comparisons of radioligand binding (e.g., ${ }^{18}$ F-FES PET) and immune recognition (e.g., immunohistochemistry assays of biopsy material).

In the earliest reported study of ${ }^{18} \mathrm{~F}-\mathrm{FES}$ PET in patients, ${ }^{18}$ F-FES uptake was seen at sites of primary carcinomas, axillary nodes, and one distant metastatic site (79). The investigators then extended the use of this radiopharmaceutical for the imaging of metastatic breast cancer. Sixteen patients with metastatic disease underwent ${ }^{18} \mathrm{~F}-\mathrm{FES}$ PET; increased uptake was seen in 53 of the 57 metastatic lesions, for a sensitivity of $93 \%$, and there were only 2 apparent false-positive results (81). Imaging results were reported quantitatively as percentage injected dose per milliliter (uptake), ratio of lesion to soft tissue, and ratio of lesion to uninvolved bone. The same group of investigators obtained similar results in a later study of ${ }^{18} \mathrm{~F}-\mathrm{FES}$ imaging in 21 patients with metastatic breast cancer; they reported $88 \%$ overall agreement between in vitro ER assays and ${ }^{18}$ F-FES PET (82). In addition to subjective analysis, ${ }^{18}$ F-FES uptake has been reported as a standardized uptake value (SUV). Using an SUV of greater than 1 to identify ER-expressing disease, Mortimer et al. (83) reported that the sensitivity of ${ }^{18} \mathrm{~F}$-FES imaging was $76 \%$, with no false-positive results, in 21 patients with metastatic breast cancer.

One of the chief advantages of ER imaging over tissue sampling for determining ER expression is the ability to evaluate the heterogeneity of ER expression. Mortimer et al. (83) found that for 4 of 17 patients (24\%) with metastatic breast cancer, there was a discordance in ${ }^{18} \mathrm{~F}$-FES uptake between sites in individuals. Mankoff et al. (80) reported the absence of ${ }^{18} \mathrm{~F}$-FES uptake at one or more metastatic sites in $10 \%$ of patients who had ER-expressing primary tumors. In this same preliminary study, the quantitative site-to-site variability in ${ }^{18} \mathrm{~F}$-FES uptake in individuals was high (coefficient of variation of approximately $30 \%$ ). A total of $13 \%$ of patients (6/47) with ER-expressing primary tumors had one or more sites of ${ }^{18} \mathrm{~F}$-FES-negative disease in a subsequent study by the same group of investigators (84). The rate of loss of ER expression at metastatic sites from ER-expressing tumors was comparable to (only slightly lower than) values obtained from tissue samples and reported in the literature $(85,86)$, suggesting that sampling error may contribute to the apparent heterogeneity in tissue-based assay studies. 
In clinical practice, in vitro ER assays are used primarily as predictive assays for endocrine therapy. Although ${ }^{18} \mathrm{~F}-$ FES PET has not been prospectively tested as a predictive assay in clinical trials, a comparison of ${ }^{18} \mathrm{~F}$-FES uptake and the response to endocrine therapy in some groups of patients has indicated the likely performance of ${ }^{18} \mathrm{~F}-\mathrm{FES}$ PET as a predictive assay. Mortimer et al. (87) showed that the level of ${ }^{18} \mathrm{~F}-\mathrm{FES}$ uptake predicted the response to tamoxifen, demonstrating the potential utility of ${ }^{18} \mathrm{~F}-\mathrm{FES}$ PET for predicting a response in the locally advanced and metastatic settings. Forty women with biopsy-proven ERexpressing breast cancer had ${ }^{18} \mathrm{~F}-\mathrm{FES}$ PET before and 7-10 $\mathrm{d}$ after the initiation of tamoxifen therapy, and tumor ${ }^{18} \mathrm{~F}-$ FES PET was assessed with the SUV method. Both the percentage decrease in ${ }^{18} \mathrm{~F}$-FES uptake (responders, $55 \% \pm$ $14 \%$ [mean $\pm \mathrm{SD}$ ]; nonresponders, $19 \% \pm 17 \%$ ) and the absolute change in tumor SUV (responders, decrease of $2.5 \pm 1.8$ SUV units; nonresponders, decrease of $0.5 \pm 0.6$ SUV units) predicted the response to tamoxifen. The level of ${ }^{18} \mathrm{~F}-\mathrm{FES}$ uptake before therapy also predicted the response to tamoxifen. The positive and negative predictive values for baseline ${ }^{18} \mathrm{~F}$-FES uptake with an arbitrary SUV cutoff of 2.0 were $79 \%$ and $88 \%$, respectively (87). No patient with an SUV of less than approximately 1.5 responded.

Linden et al. (84) showed that the initial ${ }^{18}$ F-FES uptake measurements in patients with ER-expressing tumors were correlated with subsequent tumor responses to 6 mo of hormonal therapy. Forty-seven patients with metastatic breast cancer from ER-expressing primary tumors, most of whom had been previously treated for breast cancer, many for some time and with several regimens, were given predominantly salvage aromatase inhibitor therapy. Objective responses were seen in 11 of 47 patients $(23 \%) .{ }^{18} \mathrm{~F}$ FES PET was assessed qualitatively and quantitatively with SUV and flux calculations. Although no patient without ${ }^{18} \mathrm{~F}-\mathrm{FES}$ uptake at known tumor sites responded, qualitative ${ }^{18} \mathrm{~F}$-FES PET results did not significantly predict responses to hormonal therapy. However, quantitative results were predictive of responses in that 0 of 15 patients with initial SUVs of less than 1.5 responded to hormonal therapy, compared with 11 of 32 patients (34\%) with initial SUVs of greater than $1.5(P<0.01)$. Similar results were obtained when ${ }^{18} \mathrm{~F}$-FES flux was used to measure uptake $(P<$ 0.005). Interestingly, no patient whose tumor overexpressed HER2 showed an objective response, including patients with SUVs of greater than 1.5. In the subset of patients without HER2 overexpression, 11 of 24 patients (46\%) with SUVs of greater than 1.5 responded to hormonal therapy. Hypothetically, the use of ${ }^{18}$ F-FES PET to select patients could have increased the response rates from $23 \%$ to $34 \%$ overall and from $29 \%$ to $46 \%$ in the subset of patients lacking HER2 overexpression. The timing of ${ }^{18} \mathrm{~F}$-FES imaging may have been a confounder in that study, because patients underwent ${ }^{18} \mathrm{~F}$-FES imaging while receiving aromatase inhibitor therapy, but preliminary data from the same group of investigators showed that serial ${ }^{18} \mathrm{~F}-\mathrm{FES}$ measurements changed less than $20 \%$ in patients early after the initiation of aromatase inhibitor therapy (88).

Serial PET ER imaging can be used to measure the pharmacodynamic effect of ER-directed endocrine therapy. McGuire et al. (81) demonstrated tamoxifen blockade of the ER on serial ${ }^{18} \mathrm{~F}$-FES PET scans in early studies in patients (81), similar to studies of AR blockade. Mortimer et al. (87) later showed a lower level of blockade occurring as early as $1 \mathrm{wk}$ after the initiation of tamoxifen therapy. Linden et al. (88) analyzed serial ${ }^{18} \mathrm{~F}$-FES PET scans of patients with metastatic disease undergoing treatment with different agents with different mechanisms of action: tamoxifen $(n=2)$, aromatase inhibitors $(n=14)$, and fulvestrant $(n=5)$. Patients were imaged a median of $29 \mathrm{~d}$ after the initiation of treatment. The decline in ${ }^{18} \mathrm{~F}-\mathrm{FES} \mathrm{SUVs}$ was greater with the antagonists (tamoxifen and fulvestrant) than with the aromatase inhibitors, which reduced the agonist concentration but did not block the receptor. Interestingly, qualitative ${ }^{18}$ F-FES scans obtained after treatment showed complete blockage with tamoxifen but incomplete blockage with fulvestrant in 4 of the 5 patients, despite complete blockage of uterine uptake, suggesting differential access of the drug to the uterus versus tumor sites.

Some preliminary studies have evaluated ${ }^{18} \mathrm{~F}$-FES PET in settings other than breast cancer. Moresco et al. $(75,76)$ studied ${ }^{18} \mathrm{~F}$-FES uptake in normal brain tissue and meningiomas, using measures similar to the flux measure defined earlier. Although ${ }^{18} \mathrm{~F}$-FES uptake in normal brain tissue was too low to quantify estradiol binding reliably by PET, significant ${ }^{18} \mathrm{~F}$-FES uptake was seen in some meningiomas. Selective ${ }^{18} \mathrm{~F}$-FES uptake by uterine endometrium has been shown in human imaging, with cyclic changes mirroring the menstrual cycle (89). ${ }^{18}$ F-FES uptake in endometrial cancer has been reported for a single patient studied by this method (90).

Overall, early studies of PET ER imaging have shown its promise as a tool for directing breast cancer treatment. The promising early results of the studies of Mortimer et al. (87) and Linden et al. (84) indicating the potential utility of ${ }^{18} \mathrm{~F}-$ FES PET as a predictive assay need to be confirmed in larger trials involving more institutions and objective determinations of the appropriate ${ }^{18} \mathrm{~F}$-FES SUV cutoff for predicting a response to endocrine therapy. Ongoing studies, including prospective clinical trials, should define its potential use in clinical trials and clinical practice for breast cancer and possibly other ER-expressing tumors.

\section{SSTRs}

Somatostatin is a 28 -amino-acid peptide agonist ligand secreted by endocrine D cells and neurons in the gastrointestinal (GI) tract and pancreas (91). SSTRs are membrane receptors for which 6 subtypes have been identified by molecular analysis $(45,91)$. Somatic tissues most commonly express receptor subtypes 2 and 5 (91). Somatostatin binding to the receptor activates $G$ proteins, leading to downstream physiologic actions that are tissue specific. 
Primary among these actions is the inhibition of the release of endocrine and exocrine factors in the GI system (91). Therefore, somatostatin plays an important role in the regulation of the GI tract. In addition to normal tissues, SSTRs are expressed in a variety of tumors, especially endocrine tumors, such as carcinoids, gastrointestinal and pancreatic neuroendocrine tumors, pheochromocytomas, paragangliomas, medullary thyroid cancer, and pituitary adenomas (45). Somatostatin analogs, such as the 8-amino-acid peptides octreotide and lanreotide, are used therapeutically to inhibit GI tract endocrine factor release in both nonmalignant disease (e.g., intractable diarrhea) and endocrine neoplasia, particularly pituitary and neuroendocrine tumors (91). Unlike somatostatin itself, which has a plasma halflife of approximately $2 \mathrm{~min}$, octreotide has a half-life of $1.5-2 \mathrm{~h}$, making it suitable for drug therapy $(91,92)$. In the treatment of neuroendocrine tumors, somatostatin analogs reduce the symptoms associated with excess hormone secretion and may also have direct antitumor effects (91).

The main focus of SSTR imaging has been neuroendocrine tumors and related tumors, including carcinoids, gastrointestinal and pancreatic neuroendocrine tumors, pheochromocytomas, paragangliomas, medullary thyroid cancer, and pituitary adenomas (45). Other tumors expressing SSTRs have also been studied and include lymphomas, meningiomas, ethesioneuroblastomas, and lung cancers (93-95).

Most of the work carried out to date on SSTR imaging has used labeled somatostatin analogs, most commonly, octreotide or a closely related peptide (45). Octreotide is an 8 -amino-acid peptide with stability in plasma, unlike somatostatin, which has a plasma half-life of less than $3 \mathrm{~min}$ (91). The labeling strategy is quite different from that used for a smaller molecule, such as estradiol. The first compound used in SSTR imaging, ${ }^{123} \mathrm{I}-{ }^{3} \mathrm{Tyr}$-octreotide, was introduced in 1988 (96) and used direct halogenation of a tyrosine $(45,96)$. However, the most widely used radiopharmaceuticals in current practice use a linked chelating group, such as diethylenetriaminepentaacetic acid (DTPA) or 1,4,7,10-tetraazacyclododecane- $N, N^{\prime}, N^{\prime \prime}, N^{\prime \prime \prime}$-tetraacetic acid (DOTA), that binds to the peptide and chelates a radiometal, such as ${ }^{99 \mathrm{~m}} \mathrm{Tc},{ }^{111} \mathrm{In},{ }^{68} \mathrm{Ga}$, or ${ }^{64} \mathrm{Cu}(45,97-$ 100). Currently, most clinical SSTR imaging is carried out with the agent ${ }^{111}$ In-DTPA-pentetreotide (Octreoscan; Mallinckrodt), which is approved by the U.S. Food and Drug Administration for clinical SSTR imaging (101). Recent studies $(48,98,100,102,103)$ examined octreotidelike compounds labeled with positron emitters (such as ${ }^{64} \mathrm{Cu}$ - and ${ }^{68} \mathrm{Ga}$-labeled peptides), taking advantage of the higher spatial resolution and easier image quantification offered by PET than by SPECT (104-106). Of the 2 positron-emitting labels, ${ }^{68} \mathrm{Ga}$ is conveniently available from a generator but has the disadvantage of a higher positron range than ${ }^{64} \mathrm{Cu}$.

Imaging of SSTR-expressing tumors has been applied to tumor detection and staging, prediction of the response to therapeutic somatostatin, and treatment planning for SSTR- directed radionuclide therapy $(45,92)$. The most widely tested and clinically accepted indication is tumor staging, for which SSTR imaging has become part of the clinical routine for carcinoids and other neuroendocrine tumors $(45,99,101)$. These tumors, frequently arising from the gut or other abdominal structures, can be challenging to identify by conventional anatomic imaging. Furthermore, welldifferentiated neuroendocrine tumors have fairly limited ${ }^{18} \mathrm{~F}$-FDG uptake, limiting the effectiveness of ${ }^{18} \mathrm{~F}-\mathrm{FDG}$ PET in neuroendocrine tumor staging (104). Most comparisons have shown that SSTR imaging, mostly with ${ }^{111} \mathrm{In}$ labeled compounds, has higher sensitivity and accuracy for neuroendocrine tumor localization than other modalities, supporting its ongoing use in clinical practice $(45,107)$. SSTR imaging has a significant impact on neuroendocrine tumor treatment, making it effective in clinical management (108). Combined-modality (SPECT/CT and PET/CT) imaging increases the impact of SSTR imaging, especially with regard to direct tissue sampling or surgical resection $(109,110)$. Recent studies have suggested that the use of PET labels, such as ${ }^{68} \mathrm{Ga}$, along with PET/CT may be especially effective in this regard (47). Studies have suggested that binding of the labeled peptide to the SSTR and clearance from the plasma are sufficiently rapid to permit visualization and quantification of the regional SSTR concentration by $45 \mathrm{~min}$ after injection, necessary for the short half-life of ${ }^{68} \mathrm{Ga}(111)$.

Some studies have also examined the presence or absence of uptake of SSTR imaging probes as a predictor of the response to somatostatin therapy, akin to studies of ${ }^{18} \mathrm{~F}-$ FES PET as a predictor of the breast cancer response to endocrine therapy. Although there have been some promising studies (112), the results have been variable, and this indication is less common in clinical practice than simple tumor localization and staging. Several factors contribute to the lower success of SSTR imaging than of ER imaging in response prediction: SSTR imaging studies have been mainly nonquantitative, somatostatin therapy has limited efficacy in cytoreduction, and responses are difficult to measure in slowly growing tumors, such as neuroendocrine tumors (91). The effect of SSTR-directed therapy on SSTR expression may also be a confounding factor; some studies have suggested that somatostatin itself may affect receptor expression and the uptake of labeled analogs in a complex, rather than strictly competitive, fashion (113).

A rapidly emerging focus in radionuclide-labeled SSTR ligands is SSTR-directed radionuclide therapy (92). Neuroendocrine tumors can present with advanced, widespread disease that is often refractory to conventional chemotherapy (38). However, they are often slowly growing tumors, so that minor responses or disease stabilization can result in considerably prolonged survival (114). In this regard, radionuclide therapy with labeled SSTR ligands has been effective in treating advanced neuroendocrine tumors $(92,115)$. The earliest studies used ${ }^{111}$ In-DTPA-pentetriotide and showed up to an $80 \%$ disease stabilization rate $(92,116)$. 
More recent studies have used ${ }^{90} \mathrm{Y}$ - and ${ }^{177} \mathrm{Lu}$-labeled compounds, which have some advantages over ${ }^{111}$ In-labeled compounds for radionuclide therapy. ${ }^{90} \mathrm{Y}$ is a pure $\beta$-emitter with high-energy $\beta$-emissions; ${ }^{177} \mathrm{Lu}$ has intermediateenergy $\beta$-emissions and has a longer half-life than ${ }^{111} \mathrm{In}$. Several studies have shown objective response rates higher than those obtained with ${ }^{111} \mathrm{In}$, and some recent studies have shown significant improvements in time to progression and survival $(92,117,118)$. For guiding SSTR-directed radionuclide therapy, SSTR imaging has been key (92) in showing uptake of the labeled peptide at all known tumor sites and in estimating radiation dosimetry. For dosimetry, the use of PET radiopharmaceuticals has been especially helpful (97), given the ability of PET to quantify radiopharmaceutical biodistribution.

Recent studies have suggested that radionuclide SSTR imaging fused with anatomic imaging can be very effective in targeting meningiomas (119). This approach provides another novel application of SSTR imaging in directing therapy, namely, guiding conformal radiotherapy.

In summary, radionuclide SSTR imaging and SSTRdirected radionuclide therapy have been important in the diagnosis and therapy of SSTR-expressing tumors, especially neuroendocrine tumors. Although non-receptor-based imaging with compounds such as labeled metaiodobenzylguanidine and 3,4-dihydroxyphenylalanine has also played a role in the diagnosis of these tumor types $(47,99)$, the specific imaging of SSTRs remains an important and evolving clinical tool with both diagnostic and therapeutic applications.

\section{Growth Factor Receptors}

A third and somewhat distinct receptor imaging example relates to the EGFR pathway, which has received considerable recent attention as a therapeutic and imaging target $(10,36)$. EGFR is a membrane surface receptor that interacts with agonists such as EGF and transforming growth factor; however, receptor activation is complex, and the exact nature of the ligand-receptor interaction is not completely understood $(4,39)$. It appears that activation of the EGFR pathway involves up to 4 related receptors, erbB1erbB4 (also called HER1-HER4), which form homo- and heterodimers both in the presence and in the absence of a ligand $(10,39)$. The result of these receptor interactions is the activation of a specific tyrosine kinase and a sequence of downstream reactions leading to diverse biologic consequences, which include cellular proliferation, angiogenesis, and resistance to apoptosis $(10,39)$. The EGFR pathway has been implicated in the pathogenesis of many cancer types and has received considerable recent attention as a therapeutic target $(4,10,39)$. The most notable and widely studied approaches are therapy directed to the EGFR (erbB1, HER1) for lung cancer and head and neck cancer and therapy directed to erbB2 (HER2 or HER2/neu) for breast cancer (4). Therapeutic strategies target either membrane receptors, typically with monoclonal antibodies (e.g., cetuximab for EGFR and trastuzumab for HER2), or tyrosine kinase, with small-molecule inhibitors (e.g., erlotinib for EGFR) (4).

Imaging approaches mainly parallel therapeutic approaches. Although there have been some studies of labeled receptor ligands (120-122), such as ${ }^{111}$ In-DTPA-EGF, most efforts to date have focused on receptor. Some progress has been made for specific tyrosine kinase probes (123-129); however, the multiplicity and ubiquity of tyrosine kinase expression sites as well as lipophilicity and associated nonspecific binding have made probe development challenging $(123,127)$.

The most success to date has been achieved (and the largest number of studies have been carried out) for the targeting of EGFR or HER2 by immune recognition, in parallel with therapeutic agents. Specific imaging probes have been based on radiolabeled antibodies or fragments (130-134) or on novel constructs, such as Affibodies (135,136). Most studies have been preclinical (137-141); however, some studies have reported HER2 imaging in patients $(133,142-144)$. Studies carried out by Smith-Jones et al. $(145,146)$ with a ${ }^{68} \mathrm{Ga}$-labeled $\mathrm{F}\left(\mathrm{ab}^{\prime}\right)_{2}$ fragment of trastuzumab showed the feasibility of measuring regional HER2 expression in murine animal models. The imaging results clearly demonstrated alterations in HER2 expression accompanying experimental therapy with HSP90-directed agents (geldamycin analogs) to disrupt protein chaperone functions and reduce HER2 expression (Fig. 2) (145,146). Studies with ${ }^{131} \mathrm{I}$ - or ${ }^{111}$ In-labeled trastuzumab demonstrated the ability of trastuzumab to image tumor expression of HER2 and tumor and normal tissue accumulation $(133,142,147)$, although there has been some controversy about the significance of uptake in normal tissues prone to trastuzumab toxicity, such as the heart $(133,142)$. A prom-
FIGURE 2. Images of mouse model of HER2-expressing breast cancer before treatment (A) and $1 \mathrm{~d}(\mathrm{~B}), 5 \mathrm{~d}(\mathrm{C}), 8 \mathrm{~d}(\mathrm{D})$, and $12 \mathrm{~d}(\mathrm{E})$ after treatment with 17allylamino-17-demethoxy-geldanamycin (17AAG) taken with ${ }^{68} \mathrm{Ga}-\mathrm{DOTA}-\mathrm{F}\left(\mathrm{ab}^{\prime}\right)_{2}{ }^{-}$ trastuzumab. Images show early decrease in HER2 expression shortly after 17AAG treatment, with reexpression of HER2 by day 12. Arrows indicate location of cancer. (Reprinted with permission of (145).)
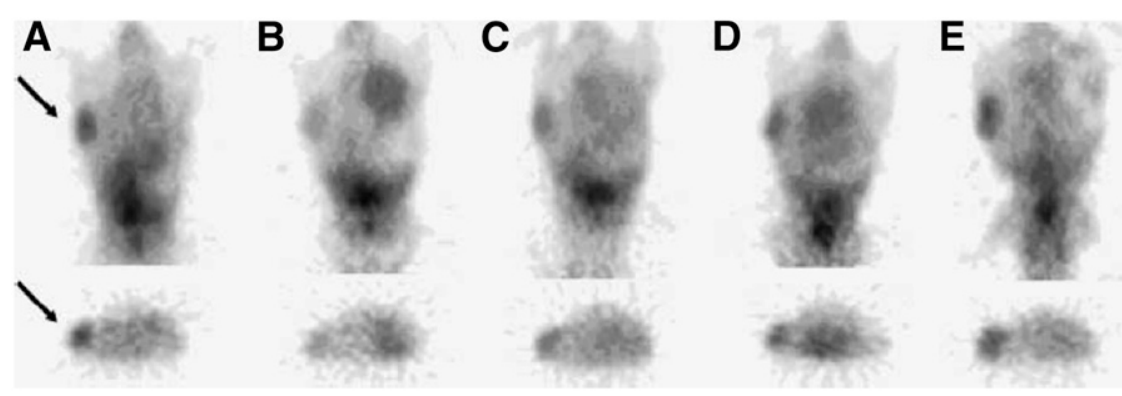
ising early study in patients was also reported for ${ }^{89} \mathrm{Zr}$ labeled trastuzumab (148). These early studies demonstrated the feasibility of HER2 and EGFR imaging, with the potential for directed therapy specific for HER2 and EGFR. In addition, recent studies suggested that altered glycolysis is an early event accompanying the interruption of the EGFR pathway $(149,150)$, suggesting a role for combined HER2 or EGFR imaging and ${ }^{18}$ F-FDG PET in predicting responses to targeted agents.

\section{OTHER RECEPTOR IMAGING MODALITIES AND APPLICATIONS}

As emphasized so far, the requirement for low concentrations of receptor imaging probes limits the choice of imaging modalities for most applications. For small-molecule ligands with a high affinity and a low capacity for receptor binding, such as the ligands used for steroid receptor imaging, radionuclide detection methods are required; the most success has been associated with high-specific-activity PET compounds (Table 1) (33,56). Peptide ligand imaging, such as SSTR imaging, is somewhat more flexible, and some success has been achieved with optical imaging probes for SSTR expression (151-154) or MRI probes for targets close to the vasculature (155). Studies of optical imaging of SSTRexpressing tumors in animal models have supported the feasibility of optical imaging of peptide ligands. Adams et al. (156) demonstrated the optical imaging of another peptide, EGF, with a fluorochrome label (157).

For imaging with monoclonal antibodies and fragments, as in HER and EGFR imaging, an even wider range of probes, such as optical, ultrasound, and MRI probes, may be possible (158-163). Koyama et al. (164) demonstrated specific fluorescence imaging of HER2-expressing lung metastases in an animal model, near-infrared imaging of HER2 expression in vitro with gold nanoshell bioconjugates was demonstrated by Loo et al. (165), and fluorochrome labeling was demonstrated by Hilger et al. (166). Similar optical approaches have been tested for EGFR imaging (167-169). Multiparameter optical imaging combining HER2 and apoptosis probes revealed target expression and an early tumor response in a mouse model, and optical approaches were used to study the response to EGFR-directed therapy in glioma models (170). Preclinical studies with specific antibodies conjugated to gadolinium or magnetic nanoparticles demonstrated the feasibility of MRI antibody imaging in cells (171) and animal models (159). The feasibility of nanoparticle-based ultrasound probes conjugated to HER2-specific antibodies was demonstrated in early in vitro studies and simulated in vivo studies $(160,172)$.

Besides detection and treatment guidance, a novel application of receptor imaging is gene therapy, in which receptors have been used as parts of PET reporter systems and receptor imaging has been used in some of the earliest studies designed to track gene transfection (173) and vector delivery (174-176). For this approach to be useful in tumor imaging, an appropriate choice of a receptor is required; typically, the receptor must be one that is not expressed by the nontransfected tumor or host tissue and for which uptake is not expected at sites at which the tumor will be imaged. Furthermore, it is important that the expression of the reporter does not elicit an immune response. Examples include the use of SSTR systems for vector delivery in non-SSTRexpressing tissues (174-176) and ER imaging for assessing gene transfection $(177,178)$.

\section{CONCLUSION}

Tumor receptors are important in the biology of many malignancies. Receptor physiology is an important component of tumor pathogenesis, growth, and metastasis. The high-affinity, low-capacity nature of most ligand-receptor systems is ideal for therapeutic interventions. Receptor imaging can survey tumor receptor expression across the entire body and is therefore ideal for guiding receptortargeted interventions. However, receptor imaging presents some challenges, most importantly, the requirement for a low molecular concentration of the imaging probe. This requirement has limited tumor receptor imaging mainly to radionuclide methods. A variety of SPECT and PET tumor receptor probes have been developed, with notable progress in peptide receptors and, more recently, in steroid receptors. Recent progress in receptor imaging for other modalities suggests that nonradionuclide receptor imaging is feasible for receptors that can be imaged with peptide ligands or antibodies. The importance of receptors in tumor biology and the abilities to predict responses to targeted therapy and to monitor drug interventions suggest that tumor receptor imaging will continue to be an important component of oncologic molecular imaging and will play a key role in cancer management.

\section{ACKNOWLEDGMENTS}

This work was supported in part by NIH grants P01CA42045, R01CA72064, and RR17229.

\section{REFERENCES}

1. Kaklamani V, O'Regan RM. New targeted therapies in breast cancer. Semin Oncol. 2004;31(2, suppl 4):20-25.

2. Osborne CK, Yochmowitz MG, Knight WA III, McGuire WL. The value of estrogen and progesterone receptors in the treatment of breast cancer. Cancer. 1980;46(12, suppl):2884-2888.

3. Sledge GJ, McGuire W. Steroid hormone receptors in human breast cancer. $A d v$ Cancer Res. 1983;38:61-75.

4. Baselga J, Arteaga CL. Critical update and emerging trends in epidermal growth factor receptor targeting in cancer. J Clin Oncol. 2005;23:2445-2459.

5. Mankoff DA, Eary JF, Link JM, et al. Tumor-specific positron emission tomography imaging in patients: $\left[{ }^{18} \mathrm{~F}\right]$ fluorodeoxyglucose and beyond. Clin Cancer Res. 2007;13:3460-3469.

6. Mankoff DA, O'Sullivan F, Barlow WE, Krohn KA. Molecular imaging research in the outcomes era: measuring outcomes for individualized cancer therapy. Acad Radiol. 2007;14:398-405.

7. Krohn KA. The physical chemistry of ligand-receptor binding identifies some limitations to the analysis of receptor images. Nucl Med Biol. 2001;28: 477-483. 
8. Krohn KA, Link JM. Interpreting enzyme and receptor kinetics: keeping it simple, but not too simple. Nucl Med Biol. 2003;30:819-826.

9. Riggs BL, Hartmann LC. Selective estrogen-receptor modulators: mechanisms of action and application to clinical practice. N Engl J Med. 2003;348: 618-629.

10. Yarden Y. The EGFR family and its ligands in human cancer: signalling mechanisms and therapeutic opportunities. Eur J Cancer. 2001;37(suppl 4): S3-S8.

11. Dorsam RT, Gutkind JS. G-protein-coupled receptors and cancer. Nat Rev Cancer: 2007;7:79-94.

12. Sherman SI, Angelos P, Ball DW, et al. Thyroid carcinoma. J Natl Compr Canc Netw. 2007;5:568-621.

13. Campbell FC, Elston CW, Blamey RW, et al. Quantitative oestradiol receptor values in primary breast cancer and response of metastases to endocrine therapy. Lancet. 1981;1:1317-1319.

14. Katzenellenbogen JA, Welch MJ, Dehdashti F. The development of estrogen and progestin radiopharmaceuticals for imaging breast cancer. Anticancer Res. 1997;17:1573-1576.

15. Katzenellenbogen BS, Fang H, Ince BA, et al. Estrogen receptors: ligand discrimination and antiestrogen action. Breast Cancer Res Treat. 1993;27: $17-26$.

16. Stein RA, McDonnell DP. Estrogen-related receptor alpha as a therapeutic target in cancer. Endocr Relat Cancer. 2006;13(suppl 1):S25-S32.

17. Hammond G. Steroid hormone action. In: Parker M, ed. Extracellular SteroidBinding Proteins. New York, NY: Oxford University Press; 1993:210.

18. Pujol P, Hilsenbeck SG, Chamness GC, Elledge RM. Rising levels of estrogen receptor in breast cancer over 2 decades. Cancer. 1994;74:1601-1606.

19. Cigler T, Goss PE. Breast cancer adjuvant endocrine therapy. Cancer J. 2007;13:148-155.

20. Dunnwald LK, Rossing MA, Li CI. Hormone receptor status, tumor characteristics, and prognosis: a prospective cohort of breast cancer patients. Breast Cancer Res. 2007;9:R6.

21. Li CI, Daling JR, Malone KE. Incidence of invasive breast cancer by hormone receptor status from 1992 to 1998. J Clin Oncol. 2003;21:28-34.

22. Kuerer HM, Buzdar AU, Singletary SE. Biologic basis and evolving role of aromatase inhibitors in the management of invasive carcinoma of the breast. J Surg Oncol. 2001;77:139-147.

23. Reed MJ, Purohit A. Aromatase regulation and breast cancer. Clin Endocrinol (Oxf). 2001;54:563-571.

24. Pan CC, Woolever CA, Bhavnani BR. Transport of equine estrogens: binding of conjugated and unconjugated equine estrogens with human serum proteins. J Clin Endocrinol Metab. 1985;61:499-507.

25. Petra P. The plasma sex steroid binding protein (SBP or SBHG): a critical review of recent developments on the structure, molecular biology and function. J Steroid Biochem Mol Biol. 1991;40:735-753.

26. Jonson SD, Bonasera TA, Dehdashti F, Cristel ME, Katzenellenbogen JA, Welch MJ. Comparative breast tumor imaging and comparative in vitro metabolism of 16alpha- $\left[{ }^{18} \mathrm{~F}\right]$ fluoroestradiol-17beta and 16beta- $\left[{ }^{18} \mathrm{~F}\right]$ fluoromoxestrol in isolated hepatocytes. Nucl Med Biol. 1999;26:123-130.

27. Tewson TJ, Mankoff DA, Peterson LM, Woo I, Petra P. Interactions of 16alpha$\left[{ }^{18} \mathrm{~F}\right]$-fluoroestradiol (FES) with sex steroid binding protein (SBP). Nucl Med Biol. 1999;26:905-913.

28. Plymate SR, Namkung PC, Metej LA, Petra PH. Direct effect of plasma sex hormone binding globulin (SHBG) on the metabolic clearance rate of 17 betaestradiol in the primate. J Steroid Biochem. 1990;36:311-317.

29. Bolt HM. Metabolism of estrogens: natural and synthetic. Pharmacol Ther. 1979;4:155-181.

30. Fink BJ, Christensen MS. Bioavailability of oestradiol and oestriol administered orally to oophorectomized women. Maturitas. 1981;3:289-294.

31. Scharl A, Beckman MW, Artwohl JE, Kullander S, Holt JA. Rapid liver metabolism, urinary and biliary excretion, and enterohepatic circulation of 16alpha-radioiodio-17beta-estradiol. Int J Radiat Oncol Biol Phys. 1991;21: 1235-1240.

32. White CM, Ferraro-Borgida MJ, Fossati AT, et al. The pharmacokinetics of intravenous estradiol: a preliminary study. Pharmacotherapy. 1998;18:13431346.

33. Katzenellenbogen J. The pharmacology of steroid radiopharmaceuticals: specific and non-specific binding and uptake selectivity. In: Nunn A, ed. Radiopharmaceuticals: Chemistry and Pharmacology. New York, NY: Marcel Dekker; 1992:297-331.

34. Clemons M, Goss P. Estrogen and the risk of breast cancer. $N$ Engl J Med. 2001;344:276-285.

35. Dickson RB, Stancel GM. Estrogen receptor-mediated processes in normal and cancer cells. J Natl Cancer Inst Monogr. 2000;27:135-145.
36. Baselga J, Cortes J. Epidermal growth factor receptor pathway inhibitors. Cancer Chemother Biol Response Modif. 2005;22:205-223.

37. Slamon DJ, Leyland-Jones B, Shak S, et al. Use of chemotherapy plus a monoclonal antibody against HER2 for metastatic breast cancer that overexpresses HER2. N Engl J Med. 2001;344:783-792.

38. Moran CA, Suster S. Neuroendocrine carcinomas (carcinoid, atypical carcinoid, small cell carcinoma, and large cell neuroendocrine carcinoma): current concepts. Hematol Oncol Clin North Am. 2007;21:395-407.

39. Scagliotti GV, Selvaggi G, Novello S, Hirsch FR. The biology of epidermal growth factor receptor in lung cancer. Clin Cancer Res. 2004;10:4227s4232s.

40. Buzdar AU. Endocrine therapy in the treatment of metastatic breast cancer. Semin Oncol. 2001;28:291-304.

41. Jordan VC, Murphy CS. Endocrine pharmacology of antiestrogens as antitumor agents. Endocr Rev. 1990;11:578-610.

42. Brueggemeier RW. Aromatase, aromatase inhibitors, and breast cancer. Am J Ther. 2001;8:333-344.

43. Bonneterre J, Thurlimann B, Robertson JF, et al. Anastrozole versus tamoxifen as first-line therapy for advanced breast cancer in 668 postmenopausal women: results of the Tamoxifen or Arimidex Randomized Group Efficacy and Tolerability Study. J Clin Oncol. 2000;18:3748-3757.

44. Dowsett M. Overexpression of HER-2 as a resistance mechanism to hormonal therapy for breast cancer. Endocr Relat Cancer. 2001;8:191-195.

45. de Herder WW, Kwekkeboom DJ, Feelders RA, et al. Somatostatin receptor imaging for neuroendocrine tumors. Pituitary. 2006;9:243-248.

46. Gabriel M, Decristoforo C, Kendler D, et al. ${ }^{68}$ Ga-DOTA-Tyr3-octreotide PET in neuroendocrine tumors: comparison with somatostatin receptor scintigraphy and CT. J Nucl Med. 2007;48:508-518.

47. Rufini V, Calcagni ML, Baum RP. Imaging of neuroendocrine tumors. Semin Nucl Med. 2006;36:228-247.

48. Wester HJ, Schottelius M, Scheidhauer K, et al. PET imaging of somatostatin receptors: design, synthesis and preclinical evaluation of a novel ${ }^{18} \mathrm{~F}$-labelled, carbohydrated analogue of octreotide. Eur J Nucl Med Mol Imaging. 2003; 30:117-122.

49. Katzenellenbogen JA. The development of gamma-emitting hormone analogs as imaging agents for receptor-positive tumors. Prog Clin Biol Res. 1981; 75B:313-327.

50. Katzenellenbogen JA, Hsiung HM, Carlson KE, McGuire WL, Kraay RJ, Katzenellenbogen BS. Iodohexestrols. II. Characterization of the binding and estrogenic activity of iodinated hexestrol derivatives, in vitro and in vivo. Biochemistry. 1975;14:1742-1750.

51. Katzenellenbogen JA. Designing steroid receptor-based radiotracers to image breast and prostate tumors. J Nucl Med. 1995;36(6, suppl):8S-13S.

52. Kiesewetter DO, Kilbourn MR, Landvatter SW, Heiman DF, Katzenellenbogen JA, Welch MJ. Preparation of four fluorine-18-labeled estrogens and their selective uptakes in target tissues of immature rats. J Nucl Med. 1984;25:12121221.

53. VanBrocklin HF, Pomper MG, Carlson KE, Welch MJ, Katzenellenbogen JA. Preparation and evaluation of 17 -ethynyl-substituted 16 alpha- $\left[{ }^{18} \mathrm{~F}\right]$ fluoroestradiols: selective receptor-based PET imaging agents. Int J Rad Appl Instrum B. 1992;19:363-374.

54. Lim JL, Zheng L, Berridge MS, Tewson TJ. The use of 3-methoxymethyl-16 beta, 17 beta-epiestriol-O-cyclic sulfone as the precursor in the synthesis of F-18 16 alpha-fluoroestradiol. Nucl Med Biol. 1996;23:911-915.

55. Mankoff DA, Tewson TJ, Eary JF. Analysis of blood clearance and labeled metabolites for the estrogen receptor tracer [F-18]-16 alpha-fluoroestradiol (FES). Nucl Med Biol. 1997;24:341-348.

56. Jonson SD, Welch MJ. PET imaging of breast cancer with fluorine-18 radiolabeled estrogens and progestins. Q J Nucl Med. 1998;42:8-17.

57. Mathias CJ, Welch MJ, Katzenellenbogen JA, et al. Characterization of the uptake of 16 alpha-([ $\left.{ }^{18} \mathrm{~F}\right]$ fluoro)-17 beta-estradiol in DMBA-induced mammary tumors. Int J Rad Appl Instrum A. 1987;14:15-25.

58. Bonasera TA, O'Neil JP, Xu M, et al. Preclinical evaluation of fluorine18-labeled androgen receptor ligands in baboons. J Nucl Med. 1996;37:10091015.

59. Dehdashti F, Picus J, Michalski JM, et al. Positron tomographic assessment of androgen receptors in prostatic carcinoma. Eur J Nucl Med Mol Imaging. 2005;32:344-350.

60. Jacobson O, Bechor Y, Icar A, et al. Prostate cancer PET bioprobes: synthesis of $\left[{ }^{18} \mathrm{~F}\right]$-radiolabeled hydroxyflutamide derivatives. Bioorg Med Chem. 2005; 13:6195-6205.

61. Larson SM, Morris M, Gunther I, et al. Tumor localization of $16 \beta-{ }^{18} \mathrm{~F}$-fluoro$5 \alpha$-dihydrotestosterone versus ${ }^{18} \mathrm{~F}$-FDG in patients with progressive, metastatic prostate cancer. J Nucl Med. 2004;45:366-373. 
62. Parent EE, Carlson KE, Katzenellenbogen JA. Synthesis of 7alpha-(fluoromethyl)dihydrotestosterone and 7alpha-(fluoromethyl)nortestosterone, structurally paired androgens designed to probe the role of sex hormone binding globulin in imaging androgen receptors in prostate tumors by positron emission tomography. J Org Chem. 2007;72:5546-5554.

63. Yang YS, Zhang X, Xiong Z, Chen X. Comparative in vitro and in vivo evaluation of two ${ }^{64} \mathrm{Cu}$-labeled bombesin analogs in a mouse model of human prostate adenocarcinoma. Nucl Med Biol. 2006;33:371-380.

64. Liu A, Carlson KE, Katzenellenbogen JA. Synthesis of high affinity fluorinesubstituted ligands for the androgen receptor: potential agents for imaging prostatic cancer by positron emission tomography. J Med Chem. 1992;35: 2113-2129.

65. Dehdashti F, McGuire AH, Van Brocklin HF, et al. Assessment of 21$\left[{ }^{18} \mathrm{~F}\right]$ fluoro-16 $\alpha$-ethyl-19-norprogesterone as a positron-emitting radiopharmaceutical for the detection of progestin receptors in human breast carcinomas. J Nucl Med. 1991;32:1532-1537.

66. Verhagen A, Studeny M, Luurtsema G, et al. Metabolism of a $\left[{ }^{18} \mathrm{~F}\right]$ fluorine labeled progestin (21-[ $\left.{ }^{18} \mathrm{~F}\right]$ fluoro-16 alpha-ethyl-19-norprogesterone) in humans: a clue for future investigations. Nucl Med Biol. 1994;21:941-952.

67. Zhou D, Carlson KE, Katzenellenbogen JA, Welch MJ. Bromine- and iodinesubstituted 16alpha, 17alpha-dioxolane progestins for breast tumor imaging and radiotherapy: synthesis and receptor binding affinity. J Med Chem. 2006;49: 4737-4744.

68. Katzenellenbogen JA, Senderoff SG, McElvany KD, O’Brien HA Jr, Welch MJ. $16 \alpha-\left[{ }^{77} \mathrm{Br}\right]$ bromoestradiol-17 $\beta$ : a high specific-activity, gamma-emitting tracer with uptake in rat uterus and uterus and induced mammary tumors. J Nucl Med. 1981;22:42-47.

69. McElvany KD, Carlson KE, Welch MJ, Senderoff SG, Katzenellenbogen JA. In vivo comparison of $16 \alpha-\left[{ }^{77} \mathrm{Br}\right]$ bromoestradiol-17 $\beta$ and $16 \alpha-\left[{ }^{125} \mathrm{I}\right]$ iodoestradiol-17 B. J Nucl Med. 1982;23:420-424.

70. Rijks LJ, Busemann Sokole E, Stabin MG, de Bruin K, Janssen AG, van Royen EA. Biodistribution and dosimetry of iodine-123-labelled Z-MIVE: an oestrogen receptor radioligand for breast cancer imaging. Eur J Nucl Med. 1998;25: 40-47.

71. Zielinski JE, Larner JM, Hoffer PB, Hochberg RB. The synthesis of 11 $\beta$-methoxy-[16 $\alpha_{-}{ }^{123}$ I] iodoestradiol and its interaction with the estrogen receptor in vivo and in vitro. $J$ Nucl Med. 1989;30:209-215.

72. Seimbille Y, Benard F, Rousseau J, et al. Impact on estrogen receptor binding and target tissue uptake of $\left[{ }^{18} \mathrm{~F}\right]$ fluorine substitution at the 16alpha-position of fulvestrant (Faslodex; ICI 182,780). Nucl Med Biol. 2004;31:691-698.

73. Seimbille Y, Rousseau J, Benard F, et al. ${ }^{18} \mathrm{~F}$-labeled difluoroestradiols: preparation and preclinical evaluation as estrogen receptor-binding radiopharmaceuticals. Steroids. 2002;67:765-775.

74. Cummins CH. Radiolabeled steroidal estrogens in cancer research. Steroids. 1993;58:245-259.

75. Moresco RM, Casati R, Lucignani G, et al. Systemic and cerebral kinetics of 16 alpha $\left[{ }^{18} \mathrm{~F}\right]$ fluoro-17 beta-estradiol: a ligand for the in vivo assessment of estrogen receptor binding parameters. J Cereb Blood Flow Metab. 1995;15: 301-311.

76. Moresco RM, Scheithauer BW, Lucignani G, et al. Oestrogen receptors in meningiomas: a correlative PET and immunohistochemical study. Nucl Med Commun. 1997;18:606-615.

77. Mankoff DA, Peterson LM, Tewson TJ, et al. $\left[{ }^{18} \mathrm{~F}\right]$ fluoroestradiol radiation dosimetry in human PET studies. J Nucl Med. 2001;42:679-684.

78. Bennink RJ, Rijks LJ, van Tienhoven G, Noorduyn LA, Janssen AG, Sloof GW. Estrogen receptor status in primary breast cancer: iodine 123-labeled cis-11betamethoxy-17alpha-iodovinyl estradiol scintigraphy. Radiology. 2001;220:774-779.

79. Mintun MA, Welch MJ, Siegel BA, et al. Breast cancer: PET imaging of estrogen receptors. Radiology. 1988;169:45-48.

80. Mankoff DA, Peterson LM, Petra PH, et al. Factors affecting the level and heterogeneity of uptake of F-18-fluoroestradiol (FES) in patients with estrogen receptor-positive breast cancer [abstract]. J Nucl Med. 2002;43:286-287.

80a. Peterson LM, Mankoff DA, Lawton T, et al. Quantitative imaging of estrogen receptor expression in breast cancer with PET and ${ }^{18}$ F-fluoroestradiol. $\mathrm{J} \mathrm{Nucl}$ Med. 2008;49:367-374.

81. McGuire AH, Dehdashti F, Siegel BA, et al. Positron tomographic assessment of $16 \alpha-\left[{ }^{18} \mathrm{~F}\right]$ fluoro-17 $\beta$-estradiol uptake in metastatic breast carcinoma. J Nucl Med. 1991;32:1526-1531.

82. Dehdashti F, Mortimer JE, Siegel BA, et al. Positron tomographic assessment of estrogen receptors in breast cancer: comparison with FDG-PET and in vitro receptor assays. J Nucl Med. 1995;36:1766-1774.

83. Mortimer JE, Dehdashti F, Siegel BA, Katzenellenbogen JA, Fracasso P, Welch MJ. Positron emission tomography with 2-[ $\left.{ }^{18} \mathrm{~F}\right]$ fluoro-2-deoxy-D-glucose and 16alpha- $\left[{ }^{18} \mathrm{~F}\right]$ fluoro-17beta-estradiol in breast cancer: correlation with estrogen receptor status and response to systemic therapy. Clin Cancer Res. 1996;2: 933-939.

84. Linden HM, Stekhova SA, Link JM, et al. Quantitative fluoroestradiol positron emission tomography imaging predicts response to endocrine treatment in breast cancer. J Clin Oncol. 2006;24:2793-2799.

85. Kuukasjarvi T, Kononen J, Helin H, Holli K, Isola J. Loss of estrogen receptor in recurrent breast cancer is associated with poor response to endocrine therapy. J Clin Oncol. 1996;14:2584-2589.

86. Spataro V, Price K, Goldhirsch A, et al. Sequential estrogen receptor determinations from primary breast cancer and at relapse: prognostic and therapeutic relevance. The International Breast Cancer Study Group (formerly Ludwig Group). Ann Oncol. 1992;3:733-740.

87. Mortimer JE, Dehdashti F, Siegel BA, Trinkaus K, Katzenellenbogen JA, Welch MJ. Metabolic flare: indicator of hormone responsiveness in advanced breast cancer. J Clin Oncol. 2001;19:2797-2803.

88. Linden HM, Link JM, Stekhova S, et al. Serial ${ }^{18} \mathrm{~F}$-fluoroestradiol positron emission tomography (FES PET) measures estrogen receptor binding during endocrine therapy. Breast Cancer Res Treat. 2005;94(suppl 1):5088.

89. Tsuchida T, Okazawa H, Mori T, et al. In vivo imaging of estrogen receptor concentration in the endometrium and myometrium using FES PET: influence of menstrual cycle and endogenous estrogen level. Nucl Med Biol. 2007;34:205-210.

90. Yoshida Y, Kurokawa T, Sawamura Y, et al. The positron emission tomography with F-18 17beta-estradiol has the potential to benefit diagnosis and treatment of endometrial cancer. Gynecol Oncol. 2007;104:764-766.

91. Low MJ. Clinical endocrinology and metabolism: the somatostatin neuroendocrine system-physiology and clinical relevance in gastrointestinal and pancreatic disorders. Best Pract Res Clin Endocrinol Metab. 2004;18:607-622.

92. Forrer F, Valkema R, Kwekkeboom DJ, de Jong M, Krenning EP. Neuroendocrine tumors: peptide receptor radionuclide therapy. Best Pract Res Clin Endocrinol Metab. 2007;21:111-129.

93. Ferone D, Semino C, Boschetti M, Cascini GL, Minuto F, Lastoria S. Initial staging of lymphoma with octreotide and other receptor imaging agents. Semin Nucl Med. 2005;35:176-185.

94. Nathoo N, Ugokwe K, Chang AS, et al. The role of ${ }^{111}$ indium-octreotide brain scintigraphy in the diagnosis of cranial, dural-based meningiomas. J Neurooncol. 2007;81:167-174.

95. Rostomily RC, Elias M, Deng M, et al. Clinical utility of somatostatin receptor scintigraphic imaging (Octreoscan) in esthesioneuroblastoma: a case study and survey of somatostatin receptor subtype expression. Head Neck. 2006;28: $305-312$.

96. Krenning EP, Bakker WH, Breeman WA, et al. Localisation of endocrinerelated tumours with radioiodinated analogue of somatostatin. Lancet. 1989;1:242-244.

97. Koukouraki S, Strauss LG, Georgoulias V, Eisenhut M, Haberkorn U, Dimitrakopoulou-Strauss A. Comparison of the pharmacokinetics of ${ }^{68} \mathrm{Ga}$ DOTATOC and $\left[{ }^{18} \mathrm{~F}\right] \mathrm{FDG}$ in patients with metastatic neuroendocrine tumours scheduled for ${ }^{90}$ Y-DOTATOC therapy. Eur J Nucl Med Mol Imaging. 2006;33:1115-1122.

98. Sprague JE, Peng Y, Sun X, et al. Preparation and biological evaluation of copper-64-labeled tyr3-octreotate using a cross-bridged macrocyclic chelator. Clin Cancer Res. 2004;10:8674-8682.

99. Sundin A, Garske U, Orlefors H. Nuclear imaging of neuroendocrine tumours. Best Pract Res Clin Endocrinol Metab. 2007;21:69-85.

100. Anderson CJ, Dehdashti F, Cutler PD, et al. ${ }^{64} \mathrm{Cu}$-TETA-octreotide as a PET imaging agent for patients with neuroendocrine tumors. J Nucl Med. 2001; 42:213-221.

101. Balon HR, Goldsmith SJ, Siegel BA, et al. Procedure guideline for somatostatin receptor scintigraphy with ${ }^{111}$ In-pentetreotide. J Nucl Med. 2001;42:1134-1138.

102. Henriksen G, Schottelius M, Poethko T, et al. Proof of principle for the use of ${ }^{11} \mathrm{C}$-labelled peptides in tumour diagnosis with PET. Eur J Nucl Med Mol Imaging. 2004;31:1653-1657.

103. Schottelius M, Poethko T, Herz M, et al. First ${ }^{18} \mathrm{~F}$-labeled tracer suitable for routine clinical imaging of sst receptor-expressing tumors using positron emission tomography. Clin Cancer Res. 2004;10:3593-3606.

104. Dimitrakopoulou-Strauss A, Georgoulias V, Eisenhut M, et al. Quantitative assessment of SSTR2 expression in patients with non-small cell lung cancer using ${ }^{68} \mathrm{Ga}$-DOTATOC PET and comparison with ${ }^{18} \mathrm{~F}$-FDG PET. Eur J Nucl Med Mol Imaging. 2006;33:823-830.

105. Junik R, Drobik P, Malkowski B, Kobus-Blachnio K. The role of positron emission tomography (PET) in diagnostics of gastroenteropancreatic neuroendocrine tumours (GEP NET). Adv Med Sci. 2006;51:66-68.

106. Wild D, Macke HR, Waser B, et al. ${ }^{68}$ Ga-DOTANOC: a first compound for PET imaging with high affinity for somatostatin receptor subtypes 2 and 5. Eur J Nucl Med Mol Imaging. 2005;32:724. 
107. Gibril F, Reynolds JC, Doppman JL, et al. Somatostatin receptor scintigraphy: its sensitivity compared with that of other imaging methods in detecting primary and metastatic gastrinomas-a prospective study. Ann Intern Med. 1996;125:26-34.

108. Lebtahi R, Cadiot G, Sarda L, et al. Clinical impact of somatostatin receptor scintigraphy in the management of patients with neuroendocrine gastroenteropancreatic tumors. J Nucl Med. 1997;38:853-858.

109. Hillel PG, van Beek EJ, Taylor C, et al. The clinical impact of a combined gamma camera/CT imaging system on somatostatin receptor imaging of neuroendocrine tumours. Clin Radiol. 2006;61:579-587.

110. Scarsbrook AF, Ganeshan A, Statham J, et al. Anatomic and functional imaging of metastatic carcinoid tumors. Radiographics. 2007;27:455-477.

111. Buchmann I, Henze M, Engelbrecht S, et al. Comparison of ${ }^{68}$ Ga-DOTATOC PET and ${ }^{111}$ In-DTPAOC (Octreoscan) SPECT in patients with neuroendocrine tumours. Eur J Nucl Med Mol Imaging. 2007;34:1617-1626.

112. Losa M, Magnani P, Mortini P, et al. Indium-111 pentetreotide single-photon emission tomography in patients with TSH-secreting pituitary adenomas: correlation with the effect of a single administration of octreotide on serum TSH levels. Eur J Nucl Med. 1997;24:728-773.

113. Gunn SH, Schwimer JE, Cox M, Anthony CT, O'Dorisio MS, Woltering EA. In vitro modeling of the clinical interactions between octreotide and ${ }^{111} \mathrm{In}$ pentetreotide: is there evidence of somatostatin receptor downregulation? J Nucl Med. 2006;47:354-359.

114. Martins RG, Rajendran JG, Capell P, Byrd DR, Mankoff DA. Medullary thyroid cancer: options for systemic therapy of metastatic disease? J Clin Oncol. 2006;24:1653-1655.

115. Bushnell D. Therapy with radiolabeled somatostatin peptide analogs for metastatic neuroendocrine tumors. J Gastrointest Surg. 2006;10:335-336.

116. Anthony LB, Woltering EA, Espenan GD, Cronin MD, Maloney TJ, McCarthy KE. Indium-111-pentetreotide prolongs survival in gastroenteropancreatic malignancies. Semin Nucl Med. 2002;32:123-132.

117. Kwekkeboom DJ, Mueller-Brand J, Paganelli G, et al. Overview of results of peptide receptor radionuclide therapy with 3 radiolabeled somatostatin analogs. J Nucl Med. 2005;46(suppl 1):62S-66S.

118. Valkema R, Pauwels S, Kvols LK, et al. Survival and response after peptide receptor radionuclide therapy with $\left[{ }^{90}\right.$ Y-DOTA0,Tyr3]octreotide in patients with advanced gastroenteropancreatic neuroendocrine tumors. Semin Nucl Med. 2006;36:147-156

119. Milker-Zabel S, Zabel-du Bois A, Henze M, et al. Improved target volume definition for fractionated stereotactic radiotherapy in patients with intracranial

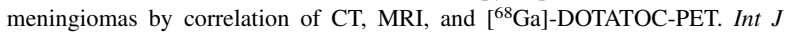
Radiat Oncol Biol Phys. 2006;65:222-227.

120. Kurihara A, Deguchi Y, Pardridge WM. Epidermal growth factor radiopharmaceuticals: ${ }^{111}$ In chelation, conjugation to a blood-brain barrier delivery vector via a biotin-polyethylene linker, pharmacokinetics, and in vivo imaging of experimental brain tumors. Bioconjug Chem. 1999;10:502-511.

121. Reilly RM, Chen P, Wang J, Scollard D, Cameron R, Vallis KA. Preclinical pharmacokinetic, biodistribution, toxicology, and dosimetry studies of ${ }^{111} \mathrm{In}$ DTPA-human epidermal growth factor: an Auger electron-emitting radiotherapeutic agent for epidermal growth factor receptor-positive breast cancer. J Nucl Med. 2006;47:1023-1031.

122. Reilly RM, Kiarash R, Sandhu J, et al. A comparison of EGF and MAb 528 labeled with ${ }^{111}$ In for imaging human breast cancer. J Nucl Med. 2000;41:903-911.

123. Bonasera TA, Ortu G, Rozen Y, et al. Potential ${ }^{18} \mathrm{~F}$-labeled biomarkers for epidermal growth factor receptor tyrosine kinase. Nucl Med Biol. 2001;28:359-374.

124. Dissoki S, Aviv Y, Laky D, Abourbeh G, Levitzki A, Mishani E. The effect of the $\left[{ }^{18} \mathrm{~F}\right]-\mathrm{PEG}$ group on tracer qualification of [4-(phenylamino)-quinazoline-6yl]-amide moiety: an EGFR putative irreversible inhibitor. Appl Radiat Isot. 2007;65:1140-1151.

125. Fernandes C, Oliveira C, Gano L, Bourkoula A, Pirmettis I, Santos I. Radioiodination of new EGFR inhibitors as potential SPECT agents for molecular imaging of breast cancer. Bioorg Med Chem. 2007;15:3974-3980.

126. Fredriksson A, Johnstrom $\mathrm{P}$, Thorell JO, et al. In vivo evaluation of the biodistribution of ${ }^{11} \mathrm{C}$-labeled PD153035 in rats without and with neuroblastoma implants. Life Sci. 1999;65:165-174.

127. Pal A, Glekas A, Doubrovin M, et al. Molecular imaging of EGFR kinase activity in tumors with ${ }^{124}$ I-labeled small molecular tracer and positron emission tomography. Mol Imaging Biol. 2006;8:262-277.

128. Shaul M, Abourbeh G, Jacobson O, et al. Novel iodine-124 labeled EGFR inhibitors as potential PET agents for molecular imaging in cancer. Bioorg Med Chem. 2004;12:3421-3429.

129. VanBrocklin HF, Lim JK, Coffing SL, et al. Anilinodialkoxyquinazolines: screening epidermal growth factor receptor tyrosine kinase inhibitors for potential tumor imaging probes. J Med Chem. 2005;48:7445-7456.
130. Bogdanov A Jr, Kang HW, Querol M, Pretorius PH, Yudina A. Synthesis and testing of a binary catalytic system for imaging of signal amplification in vivo. Bioconjug Chem. 2007;18:1123-1130.

131. Cai W, Chen K, He L, Cao Q, Koong A, Chen X. Quantitative PET of EGFR expression in xenograft-bearing mice using ${ }^{64} \mathrm{Cu}$-labeled cetuximab, a chimeric anti-EGFR monoclonal antibody. Eur J Nucl Med Mol Imaging. 2007;34:850-858.

132. Orlova A, Magnusson M, Eriksson TL, et al. Tumor imaging using a picomolar affinity HER2 binding affibody molecule. Cancer Res. 2006;66:4339-4348.

133. Perik PJ, Lub-De Hooge MN, Gietema JA, et al. Indium-111-labeled trastuzumab scintigraphy in patients with human epidermal growth factor receptor 2-positive metastatic breast cancer. J Clin Oncol. 2006;24:2276-2282.

134. Pnwar P, Iznaga-Escobar N, Mishra P, et al. Radiolabeling and biological evaluation of DOTA-Ph-Al derivative conjugated to anti-EGFR antibody ior egf $/ \mathrm{r} 3$ for targeted tumor imaging and therapy. Cancer Biol Ther. 2005;4:854-860.

135. Engfeldt T, Orlova A, Tran T, et al. Imaging of HER2-expressing tumours using a synthetic Affibody molecule containing the ${ }^{99 \mathrm{~m}} \mathrm{Tc}$-chelating mercaptoacetylglycyl-glycyl-glycyl (MAG3) sequence. Eur J Nucl Med Mol Imaging. 2007; 34:722-733.

136. Tolmachev V, Nilsson FY, Widstrom C, et al. ${ }^{111}$ In-benzyl-DTPA-ZHER2:342, an affibody-based conjugate for in vivo imaging of HER2 expression in malignant tumors. J Nucl Med. 2006;47:846-853.

137. Dorow DS, Cullinane C, Conus N, et al. Multi-tracer small animal PET imaging of the tumour response to the novel pan-Erb-B inhibitor CI-1033. Eur J Nucl Med Mol Imaging. 2006;33:441-452.

138. Meenakshi A, Kumar RS, Ganesh V, Kumar NS. Preliminary study on radioimmunodiagnosis of experimental tumor models using technetium99m-labeled anti-C-erbB-2 monoclonal antibody. Tumori. 2002;88:507-512.

139. Robinson MK, Doss M, Shaller C, et al. Quantitative immuno-positron emission tomography imaging of HER2-positive tumor xenografts with an iodine-124 labeled anti-HER2 diabody. Cancer Res. 2005;65:1471-1478.

140. Tang Y, Wang J, Scollard DA, et al. Imaging of HER2/neu-positive BT-474 human breast cancer xenografts in athymic mice using ${ }^{111}$ In-trastuzumab (Herceptin) Fab fragments. Nucl Med Biol. 2005;32:51-58.

141. Wiercioch R, Balcerczak E, Byszewska E, Mirowski M. Uptake of radiolabelled Herceptin by experimental mammary adenocarcinoma. Nucl Med Rev Cent East Eur. 2003;6:99-103.

142. de Korte MA, de Vries EG, Lub-de Hooge MN, et al. ${ }^{111}$ Indium-trastuzumab visualises myocardial human epidermal growth factor receptor 2 expression shortly after anthracycline treatment but not during heart failure: a clue to uncover the mechanisms of trastuzumab-related cardiotoxicity. Eur J Cancer. 2007;43:2046-2051.

143. Ramos-Suzarte M, Rodriguez N, Oliva JP, et al. ${ }^{99 m} \mathrm{Tc}-$ labeled antihuman epidermal growth factor receptor antibody in patients with tumors of epithelial origin: Part III. Clinical trials safety and diagnostic efficacy. J Nucl Med. 1999;40:768-775.

144. Schillaci O, Danieli R, Picardi V, Bagni O, Di Loreto M, Scopinaro F. Immunoscintigraphy with a technetium-99m labelled anti-epithelial growth factor receptor antibody in patients with non-small cell lung cancer. Anticancer Res. 2001;21:3571-3574.

145. Smith-Jones PM, Solit D, Afroze F, Rosen N, Larson SM. Early tumor response to Hsp90 therapy using HER2 PET: comparison with ${ }^{18}$ F-FDG PET. J Nucl Med. 2006;47:793-796.

146. Smith-Jones PM, Solit DB, Akhurst T, Afroze F, Rosen N, Larson SM. Imaging the pharmacodynamics of HER2 degradation in response to Hsp90 inhibitors. Nat Biotechnol. 2004;22:701-706.

147. Costantini DL, Chan C, Cai Z, Vallis KA, Reilly RM. ${ }^{111}$ In-labeled trastuzumab (Herceptin) modified with nuclear localization sequences (NLS): an Auger electron-emitting radiotherapeutic agent for HER2/neu-amplified breast cancer. J Nucl Med. 2007;48:1357-1368.

148. Dijkers E, Lub-de Hooge MN, Kosterink JG, et al. Characterization of ${ }^{89} \mathrm{Zf}-$ trastuzumab for clinical HER2 immunoPET imaging [abstract]. J Clin Oncol. 2007; 25(18S):140s.

149. Linden HM, Krohn KA, Livingston RB, Mankoff DA. Monitoring targeted therapy: is fluorodeoxylucose uptake a marker of early response? Clin Cancer Res. 2006;12:5608-5610.

150. Su H, Bodenstein C, Dumont RA, et al. Monitoring tumor glucose utilization by positron emission tomography for the prediction of treatment response to epidermal growth factor receptor kinase inhibitors. Clin Cancer Res. 2006;12: 5659-5667.

151. Becker A, Hessenius C, Licha K, et al. Receptor-targeted optical imaging of tumors with near-infrared fluorescent ligands. Nat Biotechnol. 2001;19:327-331.

152. Bugaj JE, Achilefu S, Dorshow RB, Rajagopalan R. Novel fluorescent contrast agents for optical imaging of in vivo tumors based on a receptor-targeted dyepeptide conjugate platform. J Biomed Opt. 2001;6:122-133. 
153. Licha K, Hessenius C, Becker A, et al. Synthesis, characterization, and biological properties of cyanine-labeled somatostatin analogues as receptortargeted fluorescent probes. Bioconjug Chem. 2001;12:44-50.

154. Shen D, Liang K, Ye Y, Tetteh E, Achilefu S. Modulation of nuclear internalization of Tat peptides by fluorescent dyes and receptor-avid peptides. FEBS Lett. 2007;581:1793-1799.

155. Johansson LO, Bjornerud A, Ahlstrom HK, Ladd DL, Fujii DK. A targeted contrast agent for magnetic resonance imaging of thrombus: implications of spatial resolution. J Magn Reson Imaging. 2001;13:615-618.

156. Adams KE, Ke S, Kwon S, et al. Comparison of visible and near-infrared wavelength-excitable fluorescent dyes for molecular imaging of cancer. J Biomed Opt. 2007;12:024017.

157. Gee MS, Upadhyay R, Bergquist H, Weissleder R, Josephson L, Mahmood U. Multiparameter noninvasive assessment of treatment susceptibility, drug target inhibition and tumor response guides cancer treatment. Int J Cancer. 2007; 121:2492-2500.

158. Achilefu S. Lighting up tumors with receptor-specific optical molecular probes. Technol Cancer Res Treat. 2004;3:393-409.

159. Artemov D, Mori N, Ravi R, Bhujwalla ZM. Magnetic resonance molecular imaging of the HER-2/neu receptor. Cancer Res. 2003;63:2723-2727.

160. Lee JH, Huh YM, Jun YW, et al. Artificially engineered magnetic nanoparticles for ultra-sensitive molecular imaging. Nat Med. 2007;13:95-99.

161. Liu J, Li J, Rosol TJ, Pan X, Voorhees JL. Biodegradable nanoparticles for targeted ultrasound imaging of breast cancer cells in vitro. Phys Med Biol. 2007;52:4739-4747.

162. Rosenthal EL, Kulbersh BD, King T, Chaudhuri TR, Zinn KR. Use of fluorescent labeled anti-epidermal growth factor receptor antibody to image head and neck squamous cell carcinoma xenografts. Mol Cancer Ther. 2007; 6:1230-1238.

163. Winnard P Jr, Raman V. Real time non-invasive imaging of receptor-ligand interactions in vivo. J Cell Biochem. 2003;90:454-463.

164. Koyama Y, Hama Y, Urano Y, Nguyen DM, Choyke PL, Kobayashi H. Spectral fluorescence molecular imaging of lung metastases targeting HER2/neu. Clin Cancer Res. 2007;13:2936-2945.

165. Loo C, Lowery A, Halas N, West J, Drezek R. Immunotargeted nanoshells for integrated cancer imaging and therapy. Nano Lett. 2005;5:709-711.

166. Hilger I, Leistner Y, Berndt A, et al. Near-infrared fluorescence imaging of HER-2 protein over-expression in tumour cells. Eur Radiol. 2004;14:11241129.

167. Hsu ER, Anslyn EV, Dharmawardhane S, et al. A far-red fluorescent contrast agent to image epidermal growth factor receptor expression. Photochem Photobiol. 2004;79:272-279.

168. Ke S, Wen X, Gurfinkel M, et al. Near-infrared optical imaging of epidermal growth factor receptor in breast cancer xenografts. Cancer Res. 2003;63:78707875 .

169. Keese M, Magdeburg RJ, Herzog T, et al. Imaging epidermal growth factor receptor phosphorylation in human colorectal cancer cells and human tissues. J Biol Chem. 2005;280:27826-27831.

170. Arwert E, Hingtgen S, Figueiredo JL, et al. Visualizing the dynamics of EGFR activity and antiglioma therapies in vivo. Cancer Res. 2007;67:7335-7342.
171. Funovics MA, Kapeller B, Hoeller C, et al. MR imaging of the her2/neu and 9.2.27 tumor antigens using immunospecific contrast agents. Magn Reson Imaging. 2004;22:843-850.

172. Copland JA, Eghtedari M, Popov VL, et al. Bioconjugated gold nanoparticles as a molecular based contrast agent: implications for imaging of deep tumors using optoacoustic tomography. Mol Imaging Biol. 2004;6:341-349.

173. Gambhir SS, Barrio JR, Herschman HR, Phelps ME. Assays for noninvasive imaging of reporter gene expression. Nucl Med Biol. 1999;26:481-490.

174. Belousova N, Harris R, Zinn K, et al. Circumventing recombination events encountered with production of a clinical-grade adenoviral vector with a double-expression cassette. Mol Pharmacol. 2006;70:1488-1493.

175. Rogers BE, Chaudhuri TR, Reynolds PN, Della Manna D, Zinn KR. Noninvasive gamma camera imaging of gene transfer using an adenoviral vector encoding an epitope-tagged receptor as a reporter. Gene Ther. 2003;10:105-114.

176. Yang D, Han L, Kundra V. Exogenous gene expression in tumors: noninvasive quantification with functional and anatomic imaging in a mouse model. Radiology. 2005;235:950-958.

177. Furukawa T, Lohith TG, Takamatsu S, Mori T, Tanaka T, Fujibayashi Y. Potential of the FES-hERL PET reporter gene system: basic evaluation for gene therapy monitoring. Nucl Med Biol. 2006;33:145-151.

178. Takamatsu S, Furukawa T, Mori T, Yonekura Y, Fujibayashi Y. Noninvasive imaging of transplanted living functional cells transfected with a reporter estrogen receptor gene. Nucl Med Biol. 2005;32:821-829.

179. Rijks LJ, Boer GJ, Endert E, de Bruin K, Janssen AG, van Royen EA. The $\mathrm{Z}$-isomer of 11 beta-methoxy-17 alpha-[ $\left.{ }^{123} \mathrm{I}\right]$ iodovinylestradiol is a promising radioligand for estrogen receptor imaging in human breast cancer. $\mathrm{Nucl} \mathrm{Med}$ Biol. 1997;24:65-75.

180. Tu Z, Xu J, Jones LA, et al. Fluorine-18-labeled benzamide analogues for imaging the sigma2 receptor status of solid tumors with positron emission tomography. J Med Chem. 2007;50:3194-3204.

181. Wang JQ, Gao M, Miller KD, Sledge GW, Zheng QH. Synthesis of $\left[{ }^{11} \mathrm{C}\right]$ Iressa as a new potential PET cancer imaging agent for epidermal growth factor receptor tyrosine kinase. Bioorg Med Chem Lett. 2006;16:4102-4106.

182. Velikyan I, Sundberg AL, Lindhe O, et al. Preparation and evaluation of ${ }^{68} \mathrm{Ga}$-DOTA-hEGF for visualization of EGFR expression in malignant tumors. J Nucl Med. 2005;46:1881-1888.

183. Haubner R, Wester HJ, Weber WA, et al. Noninvasive imaging of alpha(v)beta3 integrin expression using ${ }^{18} \mathrm{~F}$-labeled RGD-containing glycopeptide and positron emission tomography. Cancer Res. 2001;61:1781-1785.

184. Chen X, Conti PS, Moats RA. In vivo near-infrared fluorescence imaging of integrin alphavbeta3 in brain tumor xenografts. Cancer Res. 2004;64:8009-8014.

185. Breeman WA, Hofland LJ, de Jong M, et al. Evaluation of radiolabelled bombesin analogues for receptor-targeted scintigraphy and radiotherapy. Int $J$ Cancer. 1999;81:658-665.

186. Chen X, Park R, Hou Y, et al. microPET and autoradiographic imaging of GRP receptor expression with ${ }^{64} \mathrm{Cu}$-DOTA-[Lys3]bombesin in human prostate adenocarcinoma xenografts. J Nucl Med. 2004;45:1390-1397.

187. Montet X, Weissleder R, Josephson L. Imaging pancreatic cancer with a peptide-nanoparticle conjugate targeted to normal pancreas. Bioconjug Chem. 2006;17:905-911. 